\title{
The Muslim Chams of Northwestern Greece
}

The grounds for the expulsion of a "non-existent" minority community

\section{Lambros Baltsiotis}

\author{
(2) OpenEdition \\ Journals \\ Édition électronique \\ URL : http://journals.openedition.org/ejts/4444 \\ DOI : 10.4000/ejts.4444 \\ ISSN : $1773-0546$ \\ Éditeur \\ EJTS
}

Référence électronique

Lambros Baltsiotis, "The Muslim Chams of Northwestern Greece », European Journal of Turkish Studies [En ligne], 12 | 2011, mis en ligne le 13 décembre 2011, consulté le 16 février 2020. URL: http://journals.openedition.org/ejts/4444; DOI : 10.4000/ejts.4444

Ce document a été généré automatiquement le 16 février 2020.

(c) Some rights reserved / Creative Commons license 


\section{The Muslim Chams of Northwestern Greece}

The grounds for the expulsion of a "non-existent" minority community

\section{Lambros Baltsiotis}

1 This paper focuses on the hypothesis that the expulsion of Muslim Chams from Western Epirus during the later part of 1944 and beginning of 1945 by the guerrilla forces of EDES, resisting the Italo-German occupation occurred, contrary to conventional wisdom, not only as a result of the Chams' collaboration with the forces of occupation, but rather as an outcome of state policy, a policy which was embedded in the prevailing nationalistic ideology of the Interwar period.

2 We argue that following the earlier Greek-Turkish and Greek-Bulgarian exchanges of populations, the expulsion of Muslim Chams was part of a policy of the Greek state to exercise its alleged right to oust "non-Greeks" from its territory. Within the parameters of this ideological framework, legislatively and practically as well as domestically and internationally, the visibility of the Muslim Chams had to be lessened. The target was the minimization of their physical presence through the reduction of their numbers and the reduction of their distinctiveness as a separate religious and linguistic group.

3 In what follows we will attempt to present evidence of the growing hostility between the two religious communities (Orthodox and Muslim) of this part of Western Epirus which occurred independently of their linguistic affinities. ${ }^{1}$ This growing hostility was tolerated if not stirred by the Greek state itself. The Government and the state bureaucracy utilized an instigative approach to increase hatred between the communities in order to successfully attain the aforementioned aims.

4 Subsequently we trace the methods that the Greek governmental and public administrative bodies used in order to eradicate the presence and surviving evidence of the Muslim Chams in the area. There were two additional factors which facilitated the execution of these policies: the greater freedom of action the state felt with the imposition of a "state of emergency" in Greece starting from the period of expulsion up 
until the early 1950 s as well as the activities of the "deep" state as a powerful actor up until the fall of the Colonels' dictatorship in 1974.

\section{The land and the people}

5 During the beginning of the $20^{\text {th }}$ Century, the northwestern part of the Greek region of Epirus was mostly populated by an Albanian-speaking population, known under the ethnonyme "Chams" [Çamë, Çam (singular)in Albanian, $T \sigma(l) \alpha ́ \alpha \eta \delta \varepsilon \varsigma, T \sigma(l) \alpha ́ \alpha \eta \zeta i n ~ G r e e k]$. The Chams are a distinct ethno-cultural group which consisted of two integral religious groups: Orthodox Christians and Sunni Muslims. This group lived in a geographically wide area, expanding to the north of what is today the Preveza prefecture, the western part of which is known as Fanari [Frar in Albanian], covering the western part of what is today the prefecture of Thesprotia, and including a relatively small part of the region which today constitutes Albanian territory.

6 These Albanian speaking areas were known under the name Chamouria ${ }^{2}$ [Çamëri in Albanian, $T \sigma(l) \alpha \mu o v \rho l \alpha ́$ or $T \sigma(l) \alpha \dot{\mu} \imath \kappa o$ in Greek]. With the exception of the short lived sanjak of Reşadiye, which was founded in $1910,{ }^{3}$ this region never constituted a distinct administrative division under Ottoman rule. It was annexed to Greece in the later half of 1912, when the Ottoman Empire was retreating from a large part of the Balkan Peninsula as a result of the Empire's defeat in the First Balkan War. This was also the period when Albanian independence was declared.

7 Applying linguistic principles, the whole area constituted an Albanian speaking enclave, isolated at least in strict geographical terms, with a continuum of Albanian language in today's Albania and adjoining areas, i.e, Kosovo and the Republic of Macedonia. In the north-eastern part of that area, east to the city of Filiat(i) within Greek territory, a Greek speaking area began growing and expanding eastwards to today's Albanian territory and up to the coast of Albania.

8 According to an official document 3,676 Greek speaking and 30,726 Albanian speaking Muslims were living in the sandjak of Reşadiye. ${ }^{4}$ For the Preveza sanjak the same document provides a figure of 2,610 Greek-speaking Muslims. Based on this document it seems that more than 32,000 Muslims, plus 900 Muslim Gypsies, were unofficially recorded as living in that area annexed to Greece. ${ }^{5}$ An additional 12,640 "Albanianspeaking Greeks" were also reported to inhabit the area. These figures were relatively overstated with regards to the Muslim population and underestimated with regards to the Albanian speaking Christians. ${ }^{6}$ According to a document based on the 1920 census, after the flight of Muslim emigrants in 1913-1914, the number of the Muslims residing in Epirus fell to 26,000 persons. $^{7}$ In 1936, while some of the families had already migrated to Turkey and Albania, the Albanian Consul at Yanina (Yanya in Turkish), counting the Muslim population village by village, established the population of Chamouria at 23,048 persons. ${ }^{8}$

9 The Albanian speaking area was quite compact and well marked by the local geography, as the Greek speaking communities were settled at the eastern mountainous areas. Chamouria and Prevezaniko were also symbolically distinguished as the land where the Arvanitēes ${ }^{9}$ lived. We can rather confidently argue that Muslim and Christian Chams of the plains made up a distinct "ethno-economic" group. ${ }^{10}$ However, there was a particular pattern in the settlements of religious groups inside the area of Chamouria 
annexed to Greece: most Muslim villages were located at the center of the area, while the large majority of the Christian Orthodox Albanian speaking villages were to the south and the east of the area. ${ }^{11}$

10 Although the langue-vehiculaire of the area was Albanian, a much higher status was attributed to the Greek language, even among the Muslims themselves. Thus, during the late Ottoman era, besides the official Ottoman Turkish, Greek functioned as a second, semi-official language, accepted by the Ottoman Administration. This characteristic can be followed partly from public documents of the era.

\section{The situation prior to annexation}

11 During the late $19^{\text {th }}$ century, with the development of the Albanian national movement, the city of Yanina (the administrative center of the sanjak and the vilayet), and, to a lesser extent, Preveza in the south and the town of Filiati in the north all played an important role in promoting the expansion of Albanian nationalistic activities among Muslims. On the other hand, with the exception of certain elites and prominent families, there is no evidence that Albanian nationalist ideology had gained strong support from the local Muslim population: the pro-Albanian Leagues [Bashkimi] were quite weak in Chamouria, ${ }^{12}$ while the Albanian language schools, which appeared after the Young Turk revolution, hardly attracted any attention, despite the fact that they were established by pro-Albanian elites in the small towns of the area. ${ }^{13}$

The Albanian-speaking, Orthodox population did not share the national ideas of their Muslim neighbors and remained Greek-oriented, identifying themselves as Greeks. ${ }^{14}$ Consequently, following the annexation of the area by Greece they identified themselves with the Greek state and, concomitantly, with the Greek nation. But the fact that this Christian population was in close contact with Muslims, spoke the same language and was in geographical proximity to Albania proper was a source of constant anxiety for the Greek state. The state perception was that this partly monolingual Christian population, some of whom were ignorant of the Greek language, could easily be recruited to the ranks of Albanian nationalists. As a local writer puts it, the opening of Albanian language schools in 1909, and the consequent spreading of propaganda, constituted a "very dangerous" mixture for Christians living in the area. The same assessment had already been expressed on an official level by the Greek Consul at Yanina in $1912 . .^{15}$

13 Yet this situation was not a novelty. Prior to this period, Chamouria was already a nuisance both for the Greek state and the Christians of Epirus who identified themselves as Greeks. As the less ambitious Greek irredentists' target in 1912 was to include all the areas up to a line including Korçë-Gjirokastër-Himarë within the frontiers of the expanded Greek state, the aim was to obscure the fact that the Christian, or even the Muslim population, didn't speak Greek but Albanian. ${ }^{16}$ Concealing the existence of the Albanian language appeared as a concept as soon as the possibility of Greek expansion into Epirus appeared. Dimitrios Hassiotis, a historian and politician who supported Greek claims, writes in 1887 that in the whole of the Chamouria region, only in Paramythia do "some of the inhabitants understand the Albanian language for commercial reasons" (author's emphasis). ${ }^{17}$ The initial distortion of facts was followed by an effort to account for the allegedly "occasional" use of Albanian. This "appeal to hope" is not only applied to the distortion of the linguistic 
reality of the area as perceived by non natives, but is extended to a wider spectrum of facts and evaluations. An example of the way this "appeal to hope" was accepted as reality is that Greek officers in the interwar period truly believe that Italy and "Albanian propaganda" are to blame for the reactions of the Muslims in Chamouria and not Greek policies implemented in the area. ${ }^{18}$

The fact that the Christian communities within the territory which was claimed by Greece from the mid $19^{\text {th }}$ century until the year $1946,{ }^{19}$ known after 1913 as Northern Epirus $^{20}$, spoke Albanian, Greek and Aromanian (Vlach), was dealt with by the adoption of two different policies by Greek state institutions. The first policy was to take measures to hide the language(s) the population spoke, as we have seen in the case of "Southern Epirus". The second was to put forth the argument that the language used by the population had no relation to their national affiliation. To this effect the state provided striking examples of Albanian speaking individuals (from southern Greece or the Souliotès) who were leading figures in the Greek state. As we will discuss below, under the prevalent ideology in Greece at the time every Orthodox Christian was considered Greek, and conversely after 1913, when the territory which from then onwards was called "Northern Epirus" in Greece was ceded to Albania, every Muslim of that area was considered Albanian. ${ }^{21}$

15 The existence of a region (Chamouria) whose population was roughly half Muslim and almost entirely Albanian speaking was considered a serious problem for the Greek state, which had to be confronted both practically and discursively. Every pro-Albanian movement in these areas had to be eliminated by all means. ${ }^{22}$

\section{The pre-1923 period}

As soon as Greece annexed the lands of today's Greek Macedonia and Epirus in 1913, and Western Thrace in 1920, the state had to deal with the existence of a large Muslim population within its new territories. This population spoke a variety of languages and had a diverse social background, ranging from rich chiftlik [çiftlik in Turkish] landowners to a large number of landless workers, who cultivated the land in the chiftliks, as well as small farm-owners. The Balkan Wars, and Turkey's ensuing hostile policy towards its Greek-orthodox [Romioi] Christian populations, who demanded recognition of their national identity and declared their inclusion in the Greek nation, also affected the situation of Greece's Muslim population.

The newly annexed lands were known, in Greek legal texts and in political discourse, as

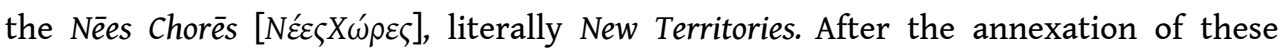
territories by Greece as a consequence of the Balkan Wars, a rather large number of Muslims who lived in these lands emigrated to Turkey, especially in the course of 1914. However, some of these people soon returned. Simultaneously, new legislation provided for the imposition of restrictions on the property rights of the Muslim population inhabiting the New Territories ${ }^{23} \mathrm{As}$ a result, the Muslim population felt uncertain about its future, partly because of the newly implemented legislation and partly due to the general political atmosphere that was prevalent at the time. ${ }^{24}$

Today there is sufficient archival evidence to support the position that, although the enforcement of the aforementioned legislation also affected the Muslims of Epirus, ${ }^{25}$ the Central Greek Government had issued specific guidelines that allowed for better 
treatment of the Muslims that were of "Albanian origin" in the New Territories. ${ }^{26}$ As a result, in certain instances the laws were not implemented in a strict fashion or in an absolutely consistent manner.

In Chamouria there were numerous chiftliks and bastaines ${ }^{27}$ which belonged to Muslim landowners ${ }^{28}$ known as beys. Although in Balkan and western historiography beys have in general been portrayed as religious, conservative and somewhat slothful oriental figures, numerous beys of Chamouria, and other Albanian speaking areas, did not correspond to this stereotype. They had internalized at least some western ideas, such as women's rights, participation in higher education, etc. At the beginning of the 20th century these beys were oscillating between the discovery of their own (Albanian) nationalism and the safety provided by belonging to the Ottoman Empire. By acting as Ottoman elites, these notables had achieved high ranks as officers of the Sublime Porte. Furthermore, there were individual beys, largely from the southern areas of Chamouria, who remained cemaat [cemaat-i İslami]oriented, even after the area's annexation to Greece. $^{29}$

Besides beys, it seems that the majority of the Muslim population consisted of middle sized estate owners. The land they owned varied in size, fertility and production. Although there is no sufficient written proof to support the idea, it's almost certain that families owning very small parcels of land, or just a few small fields and a small number of sheep, were not an exception and were also present in villages. ${ }^{30}$

21 Although Muslim Chams were not eager to fight on the side of the Ottoman army during the Balkan Wars, they were nevertheless treated by the Greek army as de facto enemies, while local Christians were enlisted in the Greek forces. For example, a few days after the occupation of the area of Chamouria by the Greek Army, 72 or 78 Muslim notables were executed by a Greek irregular military unit in the religiously mixed town of Paramythia, evidently accused of being traitors. ${ }^{31}$ During the Balkan War, in late 1912, when Muslim Chams were fighting on the side of the Ottoman Army, and Christian Chams on that of the Greek Army, several local conflicts emerged. ${ }^{32}$ While there is no Greek source describing the behavior of the Greek army against the Muslim population after they seized the area, there are several relevant descriptions in Albanian sources. ${ }^{33}$ There are only indirect (but clear) references to atrocities committed by the Greek army. ${ }^{34}$ It should be noted that in the spirit of the times, offensive acts such as defilement of mosques and, obviously, looting, would most certainly have taken place. ${ }^{35}$

22 At the same time, a freeze was imposed by the Greek state on the sale of land. Local Christians, some of them landless farmers working at the chiftliks, were impatient to improve their financial and social condition under the new "Christian" authority. From the very beginning of the area's annexation it appears that issues related to real estate and vakf property, as well as demands for raises in income, were being advanced. ${ }^{36}$ According to a law passed in 1914, the occupation of abandoned plots owned by Muslims was permitted, and from 1917 onwards this regulation was enforced even retroactively. ${ }^{37}$ The sale of land by Muslims was also forbidden from the period starting from 1913 until 1920, although it seems that the prohibition was not strictly applied throughout this period. ${ }^{38}$

23 The behavior of the Greek Army, in conjunction with the legislation implemented at the time, deeply affected the Muslims and confirmed the first serious fissure between the Christian communities and the Greek State on one side, and the Muslim 
communities on the other. Tensions between Muslims and Christians in the area began in the late $19^{\text {th }}$ century when the Christian element gradually improved its financial and social status. ${ }^{39}$ Soon after 1912-1913 it had a major ally to fulfill its ambition: the Greek state. Nonetheless, there is no strong evidence that mass migration towards Turkey occurred after the annexation of the area by the Greek State, not even in the year 1914, unlike most areas in Greek Macedonia where this was evidently the case. Despite this it is certain that there were several individuals, families and extended families that migrated to Turkey or Albania after 1913, although there is scant evidence for these individual cases ${ }^{40}$. The evidence provided by secondary sources suggests that emigrants were mostly from Paramythia and the southern region. ${ }^{41}$ It is also recorded that during the period of 1915-1916 there was a remarkable outflow of migrants to the United States. These people were departing, almost exclusively, from Filiati and the nearby villages. ${ }^{42}$

Furthermore we would argue that a second clash between the two sides occurred during the short invasion of the Italian army of the area in the spring of 1917. Although this occupation never really attracted the attention of researchers, there is evidence from the HAMFA proving that Muslim Chams received the Italian Army as their liberator. This was not only due to the fact that at that time Italy had claimed protection over Albania and was supporting Albanian interests, but mainly because Muslim Chams were persuaded that the annexation of the area to Greece was something that could be reversed, thus recovering the higher social and financial status they previously enjoyed. ${ }^{43}$ The mass enlisting of Muslims of Margariti to the Italian army ${ }^{44}$ in an area where the pro-Albanian movement was quite weak, if not totally absent, illustrates the haphazard way in which the local population delt with this issue. In the year 1919 the livelihood of the Muslim communities had been drastically reduced, putting them in a state of "misery" as described by the Greek Authorities. This situation persisted despite the fact that "violence" against Muslims and the infringements upon their properties seemed to have gradually decreased, ${ }^{45}$ albeit temporarily.

In the same period, when the Muslim Chams were still considered by Greek politicians to be Muslim rather than Albanian, theories that they were of Greek origin were sporadically reintroduced into public discourse: for example in a contemporary article they were described as "Epirotēs converted to Islam" who speak a dialect differing from Albanian and of greater affinity to Greek. ${ }^{46}$ The question of the Greek origin of Muslim Chams was a weapon to be used for many purposes. For instance, the theory of a possible common Greek-Albanian, Pelasgic (or even Illyrian) origin- very popular among Greeks and Albanians during late $19^{\text {th }}$ and early $20^{\text {th }}$ century- was initially used as an argument to pursue expansionist Greek claims in Albanian-speaking territories. This discourse of Greek or common origin of the Muslim Albanian Chams was directed to the Muslim community itself as well as international observers, Greek politicians and Greek officials of the local administration. ${ }^{47} \mathrm{~N}$. I. Anaghnostopoulos, the author of this article, was a well known agronomist/scientist of the Interwar period, closely

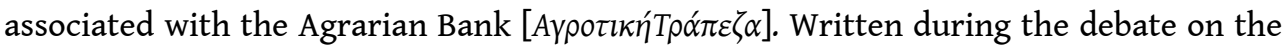
exchangeability of the Muslim Chams, his essay defends their right to remain in Greece and calls for a softer policy approach towards them. It appears that the only way to persuade the state to let them continue to live in the area was to base his argument on an assumed common origin with the Greeks. 


\section{The period 1923-1928} movement was eager to claim the loyalty or allegiance of the Slav, Greek, Aromanian and Romani speaking Muslims of Macedonia, some of whom had already migrated to Turkey. This however was not the case for the Albanian and Greek speaking Muslims of Epirus. ${ }^{48}$ The Albanian state, supported by Italian politics, opposed the exchange of the (Muslim) Albanian population of Greece, declaring that this population was Albanian and not Turkish. Finally, in 1926, that is three years after the negotiations and the diplomatic bargaining had ended, the Muslim population of Chamouria was classified as being of "Albanian origin" [ $\alpha \lambda \beta \alpha v i \kappa \eta ́ \varsigma \kappa \alpha \tau \alpha \gamma \omega \gamma \eta$ s in Greek] and was exempted from the population exchange, ${ }^{49}$ thereby surpassing the religion criterion. However, the intense diplomatic rally regarding the fate of the relevant populations, as was well described by Greek sources of that time, had a much darker and more obscure dimension. The unwavering determination of the Greek state to include the Muslims of Chamouria in the exchange of populations, alongside policies that were implemented in the field and forced upon the local population, which were in turn augmented by the determination of local officers and the local Christian population, led to extreme effects on the ground.

Some of the measures and regulations that were imposed during this period were common for all large estate owners. For example the 1920 regulation, regarding the return of a percentage of crops to the landless farmers, applied to all large landowners. However some others affected Muslims only. According to the Decree of February $13^{\text {th }}$ of 1923, the expropriation of (real estate) property was permitted for landless farmers and refugees as a measure of retribution. On October $2^{\text {nd }}$ of 1923 , the General Administration (Governorate) of Epiros announced, once again, restrictions on the sale and the renting of Muslims' properties. ${ }^{50}$

31 Furthermore, numerous land expropriations had taken place under the banner of agrarian reform. They affected the totality of landowners, most of who were to be

European Journal of Turkish Studies, 12 | 2011 
found in the New Territories. Amongst them were many Muslims. Nonetheless, it was not only the landowners of chiftliks who lost their property. Several Muslim farmers who owned a few stremmata ${ }^{51}$ of land were, illegally, included in the expropriations. A striking example of this is the case of the "Paramythia-Siametia" expropriation. In this case, the local Committee, responsible for deciding which lands were to be expropriated, determined that the whole town of Paramythia would be expropriated, including the gardens..$^{52}$ Only houses were exempt. ${ }^{53}$ Other cases include villages which had mixed population or they were situated at the edge of the Muslim inhabited area, like Petrovitsa and Dragoumi.

Most serious violations of the law and the relevant procedures regarding the expropriations of lands occurred with regard to the issue of a. the non-restitution of 300 stremmata to the owners of former chiftliks, b. the false classification of specific land possessions as bastaina -even though they were actually chiftliks-, c. the expropriations of small scale lands which were classified as chiftliks and $d$. the extreme delays, which lasted up to several years, in the issuing of decisions for compensations regarding the land that had already been expropriated. These compensations were for discreasfullylaw amounts or token payments vis-à-vis the value of the land. ${ }^{54}$ It seems that in some cases it was more opportune to declare oneself as having Albanian nationality rather than Greek since in that way it would perhaps be possible to salvage some property, such as one's houses..$^{55}$ The comparison of figures on expropriations that took place in Epirus as opposed to other areas is enlightening since it shows large discrepancies in terms of the number of expropriations that were carried out. ${ }^{56}$ Even until the early 30s, when the établis (non-exchangeable individual) certificates were issued by the Greek Authorities for the Muslims of Chamouria, the populations were not the real holders of their properties.

The presence of a population considered hostile to national interests near the frontier caused anxiety to Greek officials which was exacerbated by a militaristic perception of security and territory. ${ }^{57}$ The central Greek state was eager to push the "hostile" population to migrate to Turkey. To that end it utilized harassment tactics which were carried out by local paramilitary groups. This was a practice that was well known and had been adopted as early as the period of the Balkan Wars..$^{58}$ In other cases it just forced people to leave the country, after handing down ultimatums. ${ }^{59}$

For instance, as late as February 1925, the General Administration of Epirus undertook the task of carrying out a special operation with the purpose of persuading them to leave the country. ${ }^{60}$ Two years earlier, Greek refugees from Asia Minor had been settled in the area. These newcomers were used as a tool for applying more pressure against Muslims for them to decide to leave Greece. The newcomers took advantage of the land expropriations, and settled in the houses of Muslims. These actions were in accordance with legal provisions applicable to the whole territory of Greece.$^{61}$ It is highly probable, therefore, that some Muslims, pressed by the legislation relating to expropriation and the presence of refugees who presented a threat to them, sold their estates and remained landless. ${ }^{62}$

The restrictions imposed on the right to sell, rent or even cultivate land, due to the consideration of Muslims as "exchangeable", gradually led to the financial devastation of the Muslim population. ${ }^{63}$

In addition, it appears that there was one more specific local group whose interests clashed directly with those of Muslims: The Greek speaking mountainous population. 
These were mainly stock-breeding herdsmen, without fertile land, who had been seeking in vain an improvement of their financial position for some time. From their perspective, Chams were in possession of land which did not really belong to them, as they were not part of the nation. ${ }^{64}$

Thus, in the eyes of the Administration and the Greek population of the area, the prospect of the Chams remaining in Greece was a misfortune that had to be reversed. ${ }^{65}$ This perception would obviously guide their actions for a long time to come, until the final act of the drama was played out.

There is no evidence suggesting that the Muslim population was strongly opposed to the idea of migrating to Turkey. ${ }^{66}$ Although no one was willing to leave his/her land indefinitely, several sources indicate that as a destination Turkey was far more appealing than Albania. This was also due to the poor economic situation in the latter which was well-known to the people in the area. This phenomenon of warm regard towards migration to Turkey by the Muslims was widely used by Greek nationalist historians in order to prove the "Turkish consciousness" of the population. This notion also confused Greek politicians and diplomats of the time who, insisting on this assertion, failed to comprehend that the population had gradually been "nationalized", thus constituting a de facto Albanian national minority.

Meanwhile, measures were taken on behalf of the Greek state towards the creation of new schools and kindergartens in the Muslim villages. Koranic courses in the majority of primary schools were banned. Even relevant interpretations of the Holy Koran by

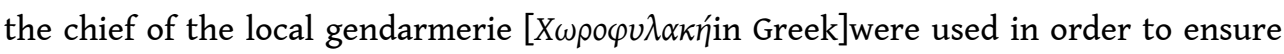
attendance of boys and girls in the new mixed schools. ${ }^{67}$ Interestingly, this was the time when the first application for the creation of a community school, whose curriculum would also include the teaching of the Albanian language, was filed. ${ }^{68}$

Parallel measures were taken at the same time regarding the language in Christian Albanian speaking villages. The most important and easily confirmed measure consisted of opening kindergartens in villages selected either by the absence of knowledge of Greek or by their demographic importance. According to a 1931 document, these villages included Aghia, Anthoussa, Eleftheri[o], Kanallaki, Narkissos, Psakka, Aghios Vlassios, Kastri (Dagh) and Draghani. ${ }^{69}$

\section{The period of the de facto existence of a national minority}

41 It was probably not until after 1926, and certainly after 1928, that Muslim Chams felt secure enough about remaining in Greece. And in this period the Greek state seemed to have come to terms with their presence. Muslim Chams had gradually started to create a type of leadership strong enough to stand up for the whole group. This leadership stood at quite a distance from the Greek political system and had intimate ties with Albania. These representatives would complain to the League of Nations against Greece, apply for the creation of schools where the Albanian language would be taught, and send their children to study in Albania. There is sufficient evidence that the Greek state's perception of the existence of a national Albanian Muslim Chams minority, living in extreme poverty, was already present in the early 1930 s. $^{70}$ 
42 A concrete description of the lives of the Muslims is clearly referred to in a special report drawn by K. Stylianopoulos, the "Inspector" in charge of Minority issues, who was directly appointed by the Prime Minister Eleftherios Venizelos and was accountable to him. The report relates to us in graphic terms that "[...] persecutions and heavier confiscations, even led to the decision of classifying as chiftlik the town of Paramythia [...] and in that way small properties and gardens had been expropriated against the Constitution and the Agrarian law; not a single stremma was left to them for cultivation and for sustaining their families, nor were the rents of their properties paid to them regularly (some of them being even lower than a stamp duty). They were not permitted to sell or buy land, and were forced to evaluate their fields at ridiculously low prices (as low as 3 drahmi per stremma), [...], only to be imprisoned for taxes not paid for land already confiscated or expropriated". ${ }^{71}$

Moreover, a matter that was also important to them besides the community wealth/ land possession concerned an entire spectrum of methodical harassment tactics against the population. ${ }^{72}$ The financial weakness of the community, and the policies of the Greek administration which intended to force them to emigrate, led finally to the (re)appearance of emigration in the early 30s. This was despite the fact that in 1931 the uncertain status of the non-exchangeability of the Muslim Chams was apparently resolved by providing them with special établis documents, ${ }^{73}$ albeit three years after the political realization that they would not be exchanged. In the eyes of the community this long delay confirmed once more that they were not welcomed by the Greek state..$^{74}$

In 1931 there was already a rather numerous Cham community originating from Greece settled in the Sarandë area. ${ }^{75}$ We are not quite sure if the emigration of Muslims, as referred to above, ever came to a halt. Nevertheless, in the years between 1932 and 1933 a new flow of migration made its appearance. ${ }^{76}$

Various documents indicate that the Greek Authorities either prompted dislocation, or, as one document vividly puts it, "all of our services, but most of all the Sub-prefecture

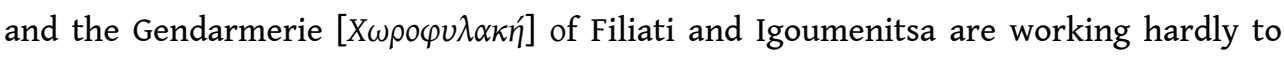
reinforce the [migration] flow". ${ }^{77}$ Practical incentives were provided to individuals and most of all to families wanting to migrate to Turkey. Another mechanism that was used in some cases was the demographic disruption of Muslim communities targeting the disassociation of the social web of the communities with a view to put additional pressure to emigrate. ${ }^{78}$

This migration flow presents a prima facie controversial acknowledgment in consideration of the fact that we have mentioned that an Albanian national minority was called into being: The great majority of the emigrants chose to leave for Turkey ${ }^{79}$ and not Albania. However, a closer reading of the relevant documents indicates that the Greek Authorities were unofficially encouraging (legal) migration to Turkey while discouraging, or even forbidding, migration to Albania. ${ }^{80}$ One more fact that should not be underestimated is that there was an underground migration to Albania, which was not documented in the reports of Local Authorities to the Centre (since, for instance, no passports were issued) and only indirectly referred to in Greek sources. However, this migration is testified to by the relevant Albanian bibliography which includes the testimonies of members of the community. This underground migration of individuals and families to Albania continued until $1940 .{ }^{81}$

It is mostly after 1932 that this flow of migration increased considerably, despite the fact that the Greek Sate at the time, at least the Government and the Ministry of 
Foreign Affairs, attempted to lessen the hitherto applied hard-line policies against Muslim Chams. ${ }^{82}$ Still, in practice these regulations were not really implemented..$^{83}$

In the 1930s it was obvious that the Chams were viewed as a hostile population and "a lost cause for "Hellenism"”. Attempts to create any kind of viable links between the community and the Greek Administration were deemed fruitless as there were few limits imposed on the hard line policies apart from the consideration of the image of the state abroad and the policies of reciprocity applied concerning the Greek Minority of Albania, which in turn had become a major national issue after the Greek Army's defeat in Asia Minor. It is evident from various documents at HAMFA that in general the Ministry of Foreign Affairs is sparing of approving the petitions of local authorities concerning deportations, prohibitions against entering Greece ("red notes") and deprivations of citizenship of males, the latter often exaggerating their reports. As it is the Ministry of Foreign Affairs which finally decides on major minority affairs, is not rare to justify its decisions on the "national interests" and the "effects on the Greek minority in Albania" when rejecting hard line proposals of the local or regional authorities, the Army and the Gendarmerie. ${ }^{84}$ On the other hand, local policy makers were often acting arbitrarily, even without informing the central administration for their acts. ${ }^{85}$

In 1935 half a dozen of teachers were appointed to teach the Albanian language, a number that gradually doubled. ${ }^{86}$ This was a measure taken on an unofficial reciprocal basis vis-à-vis Greek schools operating in Southern Albania and especially those in the Himarë region. ${ }^{87}$

For the Greeks, Muslim Chams were by now a community that was not considered as equal and was certainly treated as inferior. ${ }^{88}$ It appears that this perception was so widely accepted that it was explicitly expressed in an official text: When the Greek government was accused in front of the League of Nations in 1936 for its policy against the Albanian Minority (i.e. Muslim Chams), and with special reference to the issue of the education of children in their mother tongue, the Greek official response was as follows: "in the free public schools, they learn their local idiom through the religious teaching which is given to them in Albanian and is amply sufficient for their cultural needs". ${ }^{89}$

Finally, so as to exercise better control over the minority, the Greek state created in late 1936 a new prefecture, that of Thesprotia, consisting of areas that previously belonged to the Prefectures of Ioannina (Yanina) and Preveza, embodying all the Muslim population. ${ }^{90}$

Although not officially recognized as a national minority, Muslim Chams gradually gained an underground semi-official recognition as a national minority. As Albania became their kin-state and the discourse of the minority reproduced the typical national minority claims of the Interwar period, the Greek Administration gradually faced up to the facts. As mentioned above, it is quite interesting that the ethnonyme used in the internal administrative documents shifts from "Ottomans" and "Muslims" to "Albanians" and "of Albanian origin" in the mid 1930s. Even some newspapers in Athens refer to "Albanians" without being condemned by the authorities, although the official discourse never adopted the term "Albanian minority". This situation is vividly described in a document of 1936 sent to MFA by the Governor General of Epirus: "We would deeply appreciate your particular position regarding the national and religious minority in Chamouria. Is it considered a recognized minority or not?" (author's emphasis)..$^{91}$ 
53 In the official censuses of the Greek State in the Interwar period there is major manipulation involving the numbers of the Albanian speakers in the whole of the Greek territory. In the census of 1920 the Greek State registered 35,959 Orthodox Albanian speakers in Old Greece, the Albanian language being absent in Epirus, while in the 1928 census records for Epirus were as follows: 144 Muslims Turkish-speakers, 17,009 Muslims Albanian speakers and 2,030 Muslim Greek-speakers, completely disregarding the Christian Albanian speakers from Old Greece, by counting only 95 persons as Orthodox Albanian speakers for the whole of Greece. ${ }^{92}$ The issue here is not the underestimation of the numbers of speakers as such, but the vanishing and reappearing of linguistic groups according to political motives, the crucial one being the "stabilization" of the total number of Albanian speakers in Greece.

Language was still an issue even for Christians, especially in Western Epirus, although the state felt quite secure about their loyalty towards it. But those who live amidst Muslims in the newly created prefecture of Thesprotia continued to be classified as Albanian speaking homogeneis. ${ }^{93}$ The term homogeneis (c.f. of the same genos) was used exclusively for non Greek citizen "Greeks" living in the neighboring states, and in the case of Albania, for both Greek and non Greek speaking Orthodox of the south.

\section{The cycle of revenge}

When the Italian Army invaded Greece from Albania on October 28, 1940, an Italiansupported irredentist discourse was already present in both Albania proper and among numerous communities of Chams who had fled from Greece to Albania. Individuals who had been educated in Albanian schools, or had joined the Albanian army and Gendarmerie, acted -to use a contemporary term- as a lobby for the Muslim Cham cause. While the role of Kosovar refugees in Albanian Interwar politics has been well documented by academic research, the role played by the Cham diaspora has been overlooked. An example that shows the involvement of Cham refugees in these matters is the appointment of a Cham, rather than a Kosovar in 1935, as the head of the "Refugees Rehabilitation Committee". ${ }^{44}$

The very day Italy invaded Greece, the leaders of the Cham community were arrested and sent into exile, an action which in retrospect has been heavily criticised, as it gave the Muslim community indubitable proof of the negative perception of Greek Authorities towards the Chams. ${ }^{95}$ This measure left them without leadership, a fact that probably influenced their behaviour against the Greeks in the ensuing months. ${ }^{96}$ When the Cham refugees went to fight on the side of the Italian Army that was invading Greece, they turned against the local Christian population, who were favoured by the policies of the Greek state. In the following days however the Greek army reoccupied the area, exiled nearly the entire male Cham population, ${ }^{97}$ and turned a blind eye to the atrocities committed by local Greeks against Chams. ${ }^{98}$

The clashes that followed for several weeks should be treated as the final breach between the two communities. According to Greek historiography, the subsequent establishment of the Italian occupation forces in the area and the gradual appearance of a quasi-administrative network of Chams from late 1942 onwards are responsible for the Muslim Cham exodus that occurred in 1944 and 1945. 
In fact, the reaction of the Muslim population during the period 1941-1944 could have been foreseen. The Chams tried to regain some of their real estate property and the power they had lost during the preceding decades. ${ }^{99}$ By the year 1943 they were more systematically employed as army personnel by the German occupation Forces that took control over the area after the Italian capitulation. The trouble was not caused only by the battles against Greek resistance guerrillas. Conditions of war typically offer opportunities to shift the power-balance between different groups, and the Chams took advantage of the given circumstances in a way historically common to the area: Exhibition of their power through atrocities, murders, theft of flocks and any other type of movable property etc. could be witnessed as a recurring phenomenon. ${ }^{100} \mathrm{~A}$ striking incidence of such power games is described by Yannis Sarras. According to his account, approximately 300 armed Muslims invaded the village of Kastri, in order to take revenge for the lootings which occurred two and a half years earlier in the Muslim village of Parapotamos (ex-Varfani) by the inhabitants of the Albanian speaking, orthodox villages of Kastri and Agios Vlassios. After three days of negotiations in the village the two parties came to an agreement. Part of this agreement was the return of the domestic animals and the rest of the loot that had been taken. However when the loot was presented in front of the committee the Muslims of Parapotamos refused to accept them saying, "We came here to administer justice and our superiority" and left the village. ${ }^{101}$

The final act began to unfold when the Greek guerrilla forces of EDES, which was active in the areas inhabited by Muslims, took control of the situation at a time when the Muslim armed military forces had already been deprived of the support of the German Army. EDES $[E \Delta E \Sigma]$ was an active and powerful resistance group, operating mostly in the region of Epirus. ${ }^{102}$ The other active resistance group, which was operating over the

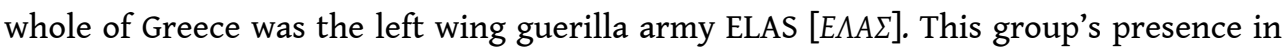
the area extended to the mountains of Mourgana in the northeastern part of the present prefecture of Thesprotia, where no Muslim settlements existed. When the Germans withdrew, battalions of EDES guerillas shot and slaughtered not only the surrendering armed forces of Muslim Chams but also women and children, a practice which they generally adopted when entering Muslim villages. This was mainly the case for the Karvounari, Parga, Trikoryfo (ex-Spatari), Filiati and most of all Paramythia towns where approximately 300 persons were murdered. ${ }^{103}$ In total more than 1,200 persons were murdered. Some Albanian sources suggest that the number is as high as approximately $2000 .{ }^{104}$ The Muslim population left the country at the end of 1944 and the local Christian population contributed to this exodus ${ }^{105}$ by looting and killing, although there were cases where local people offered protection, and thus some lives and properties were saved from the EDES guerillas and the threat posed by the armed groups or even families of local Christians.

60 A few hundred Muslims stayed behind. 127 of them were counted in the 1951 census, while the rest, whose number remains unknown and in need of research, converted to Christianity and intermarried with Greeks. ${ }^{106}$

\section{A predictable exodus}

61 It is not certain whether the ethnic cleansing that occurred during this period was part of a well organized plan. This is perhaps a question that we will never be able to answer 
given the total absence of written evidence. The assumption that the Paramythia massacres that took place on June 1944 were an ad hoc, isolated incident is rather unconvincing since it was followed by other similar events. The same tactics were used in September of the same year and were repeated again later. On the other hand, even if we assume that the massacres that happened had been spontaneous, their results were nevertheless later welcomed by the re-established Greek state after the liberation from Nazi occupation.

The conflict with the Muslims appears to have been foretold for some time: "It emerges from a great number of reports and relevant documents and published work, that Zervas seemed to have no intention of any collaboration with the Chams from the very beginning of [EDES]". ${ }^{107}$ The creation of the Cham-Albanian side-administration in the area should have played a role in the decisions of the politicians in 1945: An area south of "Northern Epirus", which all the political parties, even the Communist Party of Greece, were demanding to be annexed to Greece in 1946, had been threatened with quasi-annexation by Albania. How can the persistence of EDES fighters in attacking the unarmed and miserable Chams who had returned to the Filiati region in early $1945^{108}$ be explained if not with the purpose of their expulsion from Greece?

In 1945 and 1946 the prosecution of more than 2100 Chams, mainly males, followed. They were sentenced as war criminals and collaborators with the Occupation Forces in absentia. ${ }^{109}$ Their real estate assets (occasionally even those of their spouses and children) were subjected to general confiscation. ${ }^{110}$ The same regulations applied for the rest of the Muslim Chams, as persons "who abandoned their properties and acted against the [Greek] nation abroad". ${ }^{111}$ These confiscated properties passed onto the hands of the Greeks, and not always through formal legal means. Similarly, urban real estate properties passed to the Greek state by means of a law passed in 1938. Rural estates had the same fate after the implementation of new legislative provisions of the period between 1952 and 1959. ${ }^{112}$ All these regulations did not exclusively target the Chams. They also affected the communists who left Greece after their defeat in 1949. In addition there were more austere provisions adopted for the populations that lived near the border [ $\pi \alpha \rho \alpha \mu \varepsilon \theta o ́ p l o \zeta i n ~ G r e e k]$, which at that time included nearly all of Northern Greece. It is evident from the legislation, that the consequences of these policies, suffered by the Slav Macedonians and the Chams, were known and consciously carried out as an essential aim of the state policy during that period ${ }^{113}$ This is also proved by the fact that these regulations did not apply to the Muslim Turks of Western Thrace who left Greece after 1940. ${ }^{114}$

\section{The disappearance of the minority and "ethnic cleansing"115}

The atrocities that took place against the Muslim population are not mentioned in any official documents. They are absent even from confidential documents exchanged between the administrative bodies themselves. ${ }^{116}$ This does not only demonstrate that the Cham issue was a closed case for the Greek state but it also suggests that the state wished to completely eradicate any evidence of what had happened during that turbulent period. 

writers undertook the task of presenting the "realities" of the period of war, with the implicit aim of justifying the ethnic cleansing that had taken place. A few years after the expulsion, a propaganda booklet was published entitled "Chams and Chamouria. Descendants of perjurers--Yesterday's collaborators with the Occupation Forces and war criminals-Today's chiefs of the communist gangs". ${ }^{117}$ The booklet referred to the crimes of the Chams even though "the Greek state stood scandalously in favour of [them]". The writer is making an argument for the Greek origin of the Chams, who according to him were converted to Islam and were "obliged in time to learn the Albanian language," and estimates their number at16,661. ${ }^{118}$ This booklet was the second printed work that made reference to the case. The first one was published in $1945,{ }^{119}$ but never attracted any attention. As Giorgos Margaritis notes, the theory arguing for a natural criminal tendency among the Chams was put forward and, in a fashion also adopted by the later booklet, was meant to justify the bloody cleansing of the minority. ${ }^{120}$ During the interwar period a similar theory had been used to explain the financial destruction of the community: It was a result of their laziness and their dislike of education. dominant after the exodus. The aim was to prove that all the lands that comprised Chamouria had been inhabited by Greeks in fact, that the whole of the Greek territory had a purely Greek history which could not have been claimed by foreign states and opponent national histories, protecting the unredeemed part of their nation, so the solution was to consider them former Greeks who betrayed their nation by converting to Islam in the first instance and by identifying themselves with an alien nation in the second. The territory was claimed through its population, which in the era of the nationalities principle became the normative approach.

Another book entitled Grief and tears of Thesprotia, published most probably in the late 1960s, repeats the assertion that the Muslims of the area were local Greeks converted by force to Islam and forced to learn the Albanian language. The Muslims of Thesprotia were counted at 16,661 , once again through playing with the numbers of the unofficial figures of the 1940 census. ${ }^{121}$ The writer refers to the "outrageous favours" they enjoyed due to the efforts of the Greeks and the Greek state and describes the crimes of those "human-looking monsters". ${ }^{122}$

In 1986 Vassilis Krapsitis published what turned out to be the most popular book to that date. A large part of it is dedicated to the atrocities committed by Muslims, while reference to the Paramythia massacre occupies no more than a footnote. The narrative of the Greek origin of the Chams is repeated, just like the arguments about their forced conversion to Islam and their Greek-mother tongue, for a majority of the population. Following the 1940 census the author claims that 18,576 Muslims were registered in the area. ${ }^{123} \mathrm{~A}$ year earlier, the same author had published another book, dealing with the history of the town of Paramythia. Evidently, there were certain chapters focusing on "War crimes" of Muslim Chams but utter silence on the Paramythia massacres. More importantly, the same book includes a sub-chapter entitled "[The Paramythia Muslims].Full Greeks converted to Islam", where the usual references and arguments are made. ${ }^{124}$

69 A slightly different approach appears in the writings of Spyros Mousselimis, a local teacher. In his major work, first published in 1973 but best known after its 1997 edition, he accepts the forced conversion theory, and takes a step further, declaring that the

European Journal of Turkish Studies, 12|2011 
Albanian $[\alpha \rho \beta \alpha v i \tau$ ik $\alpha$ in the original text] language of "Christian and Turk Chams" has Greco-Pelasgic roots and that both were descendants of the Dorians. He avoids focusing on the 1940-1945 period, except for scattered references, one of which was the looting and burning of the Muslim village of Gardiki. In a line he refers to the "revenge and pogrom" against the "Turks" at Paramythia by the guerrillas. ${ }^{125}$

These publications going back as far as the mid 1980s clearly show a deliberate erasure of memory regarding the Muslim Chams from public discourse. What is specifically understated each time is the fact that for a lot of Christians of the area Albanian remained their mother tongue. ${ }^{126}$

71 In contrast, prior to the 1990s there were only two books that had the courage to address the facts. The first one, written by a local named Yannis Sarras, member of the leftist resistance organisation EAM, reveals the atrocities against Muslim Chams, by reference to distinct incidents. His book, although not well known and difficult to find even at the time it was published, is also the only one that examines the Albanian linguistic tradition of the area. ${ }^{127}$ The second book is written by a member of the armed leftist resistance group $E \Lambda A \Sigma[E L A S]$, in which the atrocities and murders against the Muslim population are also described. ${ }^{128}$

The fact that from the early 1980s onwards the Albanian-speaking communities of Southern Greece started to investigate their roots and linguistic traditions necessitated the invention of yet another conceptual construction. This new concept appeared at the same time with reference both to the Arvanitic communities of southern Greece and to the Chams. In 1989 Krapsitis published a book on the (Christian Cham) Arvanitess. In that book herepeats the constructions regarding their origin and their (proto-) Greek language, ${ }^{129}$ as an attempt to disconnect them from the Muslim Chams. Simultaneously, an attempt is made to disconnect their language from proper Albanian, the corresponding standard official language, stating that it is not Albanian but Arvanitic, an idiom quite similar with the arvanitika language spoken in Southern Greece. ${ }^{130}$

The theory of the Greek origin of the Chams appears even in scientifically oriented works. As it often happens in such cases, sources are purposefully left without verification. In the following example a Greek propaganda book is employed to support the hidden argument that those lands were inhabited by Greeks: "these Albanian speaking Moslems, who were descendants of the Christian inhabitants of Thesprotia and who had been converted to the Muslim religion and had lost contact with the Greek language during the Ottoman rule" (author's emphasis). ${ }^{131}$ In one sentence, the writer manages to support the Greekness of the people and of the area. They were autochthonous, so there were no "population invasions"; they were Greeks who "lost" their language and Christians (the other accompanying trait of Greekness) who lost their faith; those facts changed due to the evil "Ottoman rule". These conclusions are based on two footnotes from the book of Ioannis Archimadritis, a propaganda book par excellence.

The erasure of the Cham past in general was further assisted by the fact that the Chams were considered to be a "hostile population"132 even in communist Albania, a black sheep in the "heroic resistance of the Albanian people". ${ }^{133}$ Leonidas Embirikos has pointed out that there is a complete absence of works by local authors presenting the history of their village, in contrast to a common practice throughout Greece. ${ }^{134}$ If we consider that even in the case of Macedonian/Bulgarian speaking villages there are at least a dozen books on the history of the villages, with some actually making direct or indirect 
references to their linguistic alterity, we presume that in the case of Chamouria there are two issues that local authors do not want to deal with: the linguistic alterity, a common language with Muslims (and Albanians) and the 1944-1945 incidents.

In view of the above, the sudden reappearance of the Cham issue in Albanian political and public discourse surprised and frightened Greece in every respect. Greek semiofficial discourse was based on propaganda books and leaflets published in the previous decades and was unable to address the evidence that sprang forth from the opposite side. Even local Greeks were frightened, as they started to worry about their properties. It is in this context that in 1993 when the Cham issue was already being discussed in Albania, a scholarly book attempted to reconstruct the history of the interwar period. In this book, arguments related to the Greek origin of the Muslims are supported and the non-Albanian national consciousness of the Chams is emphasised. With regard to the whole spectrum of the issues specific to this period, key questions such as the property issue and past discriminatory policies are not examined. There is a mention of the unsuccessful denunciation by the Albanian Government to the League of Nations in 1928. At this point the writer conflates the issue of Greek refugees (from Turkey) with that of the estate policies, a common trick, aimed at justifying Greek positions. ${ }^{135}$

From mid-nineties, with the emergence of the issue in bilateral Greek-Albanian politics, a few more publications came into view. ${ }^{136}$ Their common aim was to emphasize the "criminal behavior" of Muslim Chams and conceal the ethnic cleansing they were subjected to. The theories of Greek origin and forced conversion to Islam were still present. ${ }^{137}$

Krapsitis' 1986 book and Michalopoulos' book, are easily found in bookstores accessible to the wider public. These are the two books which have shaped public ideas on the Cham issue.

79 In all these published works it is common practice to focus only on numbers of Albanian speaking Muslims, leaving out those who were considered by the Greek censuses as Greek speaking. In this manner the total number of Chams is underestimated as a mere 2,000 persons. ${ }^{138} \mathrm{But}$ even when presenting the census the authors use various ploys in order to reduce the number of Muslims. Although Krapsitis in his 1986 book counts 18, 576 Muslims according to the unofficial data of the 1940 census, others using the same census arrive at a figure of 16,661 persons, following Chariton Lambrou's lists. Lambrou used rather primitive manipulations in order to reduce the number of the Muslim population: He totally omitted the Muslim population of certain villages ${ }^{139}$ and in villages where there was a mixed population the count for Muslims is transferred to the category of Christians and vice versa. ${ }^{1{ }^{10}}$ Besides, there is enough evidence to prove that even "Krapsitis' census" underestimates the Muslim population for at least 2,500 persons. ${ }^{141}$

The stigma of the killings, or as we name it the blood stigma, which is carried by the local Christian population, helped the administration to make the Cham issue absolutely disappear from public discourse. Unlike the case of Slav-Macedonians, Muslim Chams were all gone, with no signs of any natural presence after the War. By collaborating with the Occupation Forces they had also lost their support from the Left. ${ }^{142}$ Moreover the local Christians generally benefited from the expulsion in addition to the fact that quite a lot took part in the 1944-1945 incidents. Consequently, it was easy for state institutions to render the Chams invisible. 
81 be concealed also, since the language was perceived as an additional threat to the Greekness of the land. It could only be used as a proof of their link with the Muslims, thus creating a continuum of non-Greekness. ${ }^{143}$ In this way, in the History of the Greek

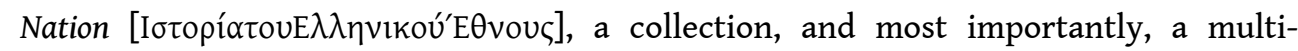
volume work with the official purpose of securing as well as of normalizing Greek history, the Albanian language is reportedly absent in the south of the Souha line.In other words, south of Himarë-Gjirokastër-Suhë-Leskovik the population was Christian and Greek speaking. ${ }^{144}$

The process of extinguishing any signs of previous minority existence occurred both in real and symbolic ways. The villages of Muslim Chams were repopulated by Greek speaking populations from the adjacent mountainous areas and Vlachs, immediately after their expulsion. The central Holy Mosque of Paramythia was not only blown up but was symbolically gouged in order to underline the end of the Muslim presence in the area. ${ }^{145}$ Gradually, in a period of less than ten years, nearly all mosques and especially minarets, visible symbols of Muslim presence, were demolished. ${ }^{146}$ One of the last acts of the "cleansing of history" is the blowing up of the mosque at the village of Polyneri (ex-Koutsi,) by a (Christian) villager, during the time of the Colonels' Dictatorship. ${ }^{147}$ A tiny Muslim community and, until recently, the last imam of Epirus still survive in this village. ${ }^{148}$

What has turned the Chams into an absolutely invisible minority is the erasure of their existence from every public registration roll. In their case it seems that the withdrawal of their citizenship was not the outcome of a legal procedure. In accordance with the regulations in force at the time (under article 4 of the 12.08.1927 Decree) persons not

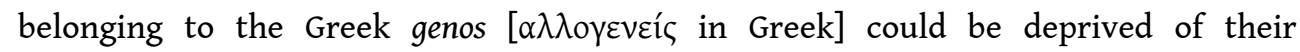
citizenship if they had left Greek territory with no intention of return. ${ }^{149}$ Even though the legal paths of these deprivations of citizenship can be traced for the cases of SlavSpeaking Macedonians, Muslim-Turks, Jews and other groups deprived of their citizenship rights, this is not the case for Muslim Chams. Seemingly, a different procedure was employed for them. The reason for this difference is, we presume, that what we are dealing with in the Chams' case it is not an issue of deprivation of citizenship through individual decisions, issued by the prefect/the Ministry of Interior (Affairs) and the Ministry of Military Affairs, but rather an erasure or destruction of all relative documents. Specifically, this refers to the destruction of the municipality

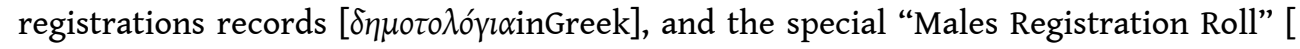

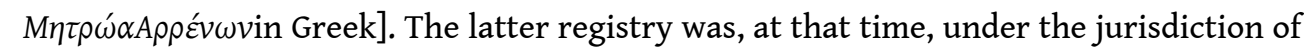
the Ministry of Military Affairs. According to a document classified as "urgent and secret" of the Ministry of Military Affairs to the Recruiting office of Igoumenitsa and the Prefecture of Thesprotia (doc. А. П. 50862/Ф. 38254, Athens, the $16^{\text {th }}$ of Dec. 1947) the Ministry directed the above mentioned local authorities to erase the names of Muslims from the Males Registration roll as they were considered as being already deprived of their Greek citizenship (under the 1927 Decree). ${ }^{150}$ Today, no registration of a Muslim Cham can be traced in the municipality or Males registries. ${ }^{151}$ Municipalities, on the other hand, have fabricated untenable justifications for this irregularity. ${ }^{152}$ It is worth mentioning that the deprivation of citizenship was also implemented in Epirus, in the remaining population of Moslems, numbered a few hundred persons, in accordance with article 19 of the Greek Nationality Code (Act) up until its revocation in 
1998. ${ }^{153}$ The implementation of article 19 in Epirus demonstrates best that the state policy was that the slightest sign of Muslim Cham existence in the area had to be eradicated.

\section{Conclusion}

84 It could be argued that it was not officially the state that committed ethnic cleansing, an argument put forth worldwide by various states and for a variety of similar cases. In the Cham case, however, the state herself was both undisturbed by this ethnic cleansing and received its results favorably. Napoleon Zervas, the leader of EDES, was considered a hero by the state and had a subsequent career as a prominent member of the political system. Furthermore, the state backed up the ensuing absolute obliteration of Chams. Their expulsion was far from being perceived as an "historical mistake": it was seen as an act of salvation for the area and for Greece at large. ${ }^{154}$

As we have shown, the continuous anxiety of the Greek authorities to reduce as much as possible the existence of the minority and to mute the development of a national Albanian minority in Chamouria, was transformed into physical expulsion when these measures were not deemed sufficient. This "reduction" included the numbers of persons and their representation in registries, their land and property, leading to a reduction finally in their total presence, their national affiliation and their entitlement to fair treatment. The dominant perception was that the lands near the border had to be Greek, not only because it adjoined the frontier of another state, but also because it was inconceivable after the Lausanne Treaty that a non-Greek in every sense (i.e. religion and language) could own Greek land, or simply exist inside Greek territory, while claiming not to be Greek. In this sense the compactness of the Albanian speaking area in Western Epirus, from a certain period onwards, did not constitute a danger to the Greek state in terms of a possible shift of its Christian Albanian speaking population towards Albania. The danger lay in the fact that this land could continue to be viewed as Albanian, the land of Arvanitēs (see above). "[T]he idea of "hellenising" the land of the Chams was made possible by the ideology of human exchanges and the lack of legal protection for these minorities during the interwar period", 155 as stated by Georgia Kretsi. This deep rooted anxiety of the Greek state, as disclosed by the patterns of policy implementation in the region, led to the gradual minoritization and nationalization of the group, ${ }^{156} \mathrm{a}$ process that shaped its complete and utter exclusion from the Greek nation-state. Following these processes the next step for a solution to the issue was their expulsion, given that there would be no major bilateral or international risk of protest and conditions of war presented the most favorable chances for a total expulsion to take place. The expulsion was facilitated by the general tendency of Eastern European states to proceed to the mass expulsion of their German minorities at the end of the War through the argument of the explicit intervention of the German state, as well as their open identification with Germany.

The intention of the State was quite clear: the expulsion of Muslim Chams through their inclusion in the Greco-Turkish population exchange. Although not realized through this exchange, state policies directed at the reduction of the population of Muslim Chams were a prelude to the expulsion that would take place later. The exact time and means of this expulsion were under a constant process of negotiation. We argue that the intention of the state found, at the time, nomination in the actions of the 
Armed Forces which were acting as forces of national resistance. These forces, in the presence of an absent or later weak state and with its blessing, were acting on behalf of the "nation" and the state. As the state gained back its strength, the actions of the guerilla forces were accepted as the state's own operational policy. When we look at other war-related cases in the postwar Greek state, despite its staunch anticommunism and partial staffing by members of armed groups responsible for atrocities, there still were cases where individuals responsible for atrocities were sentenced and were far from being rewarded. The absolute "non punishment" and the "reward" of those individuals related to the expulsion of Chams, are strong indicators that these policies were both accepted and formed part of state policy.

The total disappearance of an albeit officially unrecognized minority that once existed was disturbed only after the emergence of the issue in post-communist Albanian politics. But less than fifty years were sufficient to erase all memory of the Chams from the minds of the Greeks. With the exception of the locals themselves, everyone else in Greece, from politicians to most historians, ${ }^{157}$ is convinced or pretends that (Muslim) Chams never existed in Greece. The process of erasure/muting was so successful, that even the anchormen of Greek television speak of "the pseudo-Chams" or "the self-so-called Chams".

87. For the importance of the operation of Greek schools at Himarë and the significance it played at the decision of the Greek Administration to permit the instruction of the Albanian language in a few schools see E. Manda..., op. cit., p. 105, where relevant Albanian and Greek sources sited. Although the instruction of the Albanian language is related on the point of time with the opening permission of private schools for the Greek minority in Albania and such reciprocity tactics are traced in Albanian archives (see N. Clayer "L'albanisation de la zone frontière albanogrecque et ses aléas dans l'entre-deux-guerres", Actes du colloque Frontières et territories dans les Balkans, EFA, Athènes, September 2006 (under publication)), there is no relevant evidence in Greek archives.

\section{NOTES}

1. It's worth mentioning that the Greek speaking Muslim communities, which were the majority population at Yanina and Paramythia, and of substantial numbers in Parga and probably Preveza, shared the same route of identity construction, with no evident differentiation between them and their Albanian speaking co-habitants. These last mentioned Muslim communities were in some cases bilingual in Greek and Albanian (see the specific chapter "La question de la langue dans quelques villes et bourgades de l'Épire”, in Lambros Baltsiotis,L'albanophonie dans l'État grec. Expansion et déclin des parlers albanais, diplôme de l'EHESS, Paris, 2002, pp. 305-312).

2. In certain sources Chamouria includes the Greek-speaking area to the east of the city of Filiati and does not include the Albanian speaking area of Fanari, named alternatively "Prevezaniko". The official name of the area north of the Acheron river is Chamouria in all Greek state documents for the whole Interwar period. 


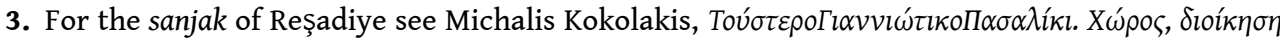

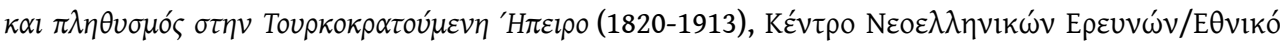

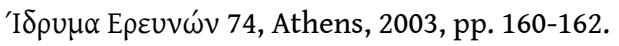

4. EleftheriosVenizelosArchive, f. 8/1913 “ $\Sigma \tau \alpha \tau \imath \sigma \tau \imath \kappa o ́ \varsigma ~ \pi i ́ v \alpha \xi ~ \pi \lambda \eta \theta u \sigma \mu o u ́ ~ B \imath \lambda \alpha \varepsilon \tau i ́ o v ~ I \omega \alpha v v i ́ v \omega v$

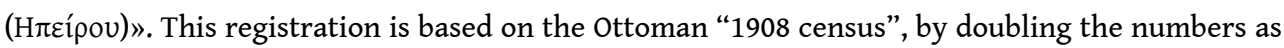
only males were counted at 1908. It seems that the language figures are estimations made by Greek officials. For the Ottoman census of 1908 and its accuracy, see K. Kokolakis, ..., , op. cit., pp. 276-277, 509.

5. This figure does not include more than 4500 inhabitants of the Muslim villages of the Konispol area of the kaza of Filiati annexed to Albania.

6. See L. Baltsiotis, L'albanophonie..., op. cit., pp. 272-280.

7. Historical Archive of the Ministry of Foreign Affairs (HAMFA), Athens, 1923, file 6.7. After this document the number of Muslims was estimated as following: a) at the Prefecture of Jianina: 2,300 Greek speaking, 700 Turkish speaking and 16,500 Albanian speaking b) At the Prefecture of Preveza: 900 Greek speaking, 300 Turkish speaking, 5,300 Albanian speaking and 100 Romani speaking. According to various estimations the Muslim population of the town of Yanina did not exceed 2,200 persons, while a reasonable estimation for the rest of the prefecture, excluding the area that later formed the prefecture of Thesprotia and the town of Parga, would lie between 10 to 15 hundred persons.

8. See Kaliopi Naska (ed.), Dokumente për Çamërinë (1912-1939), Drejtoria e Përgjithshme e Arkivave, Tirana, 1999, pp. 682-685. The Consul mentions that around six hundred persons should be added to the numbers for the Filiati region, as his records are not accurate for this area. He also notes that seven hundred people from this area had migrated to Turkey. He assumes a maximum of 25 to 28,000 Muslim Chams residing in the area.

9. Until the Interwar period Arvanitis (plural Arvanitēs) was the term used by Greek speakers to describe an Albanian speaker regardless of his/hers religious backround. In official language of that time the termAlvanos was used instead. The term Arvanitis coined for an Albanian speaker independently of religion and citizenship survives until today in Epirus (see Lambros Baltsiotis and Léonidas Embirikos, "De la formation d'un ethnonyme. Le terme Arvanitis et son evolution dans l'État hellénique", in G. Grivaud-S. Petmezas (eds.), Byzantina et Moderna, Alexandreia, Athens, 2006, pp. 417-448.

10. See L. Baltsiotis, L'albanophonie..., op. cit., p. 29, where one can also find examples of the ethnic division between the Greek speaking and Albanian speaking Christian population, even at Fanari. 11. The western limit of the area is the Ionian/Adriatic coast. For a detailed enumeration of the Albanian speaking settlements of the area and their religious identity, see ibid, pp. 272-311, 393-397, 422-428 et Annexes pp. 552-594.

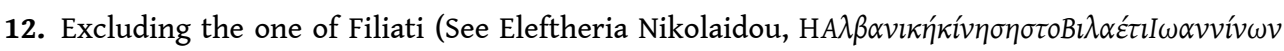
$\kappa \alpha i \eta \sigma v \mu \beta 0 \lambda \eta \dot{\tau} \omega \nu \nu \varepsilon \sigma \chi \omega^{\prime} v \sigma \tau \eta v \alpha v \alpha \dot{\pi} \tau v \xi \dot{\eta} \tau \eta \varsigma$, E.H.M.-I.M.I.A.X., Yanina 1984, passim).

13. For a description of the Leagues and the educational initiatives in Chamouria, Preveza and Yanina, see Leonidas Embirikos, Histoire de la langue albanaise en Grèce de la création de l'État hellénique jusqu'à nos jours, Diplôme de l'EHESS, Paris 2002, pp. 117-120 and E. Nikolaidou,..., op. cit., passim).

14. We consider as the following reasons to have led to the near complete absence of proAlbanian feelings amongst the Orthodox population of the area: a. the non existence of an Albanian speaking Christian elite, made up of both landowners and merchants. In any case, a well educated orthodox coming form the orthodox Albanian speaking community can hardly be located in Chamouria b. A rather large percentage of the Christian population consisted of landless farmers and small scale land owners who lived in comparatively small villages. $c$. The larger settlements were Greek-speaking or Greek-speaking oriented independently of the religion of the inhabitants $d$. The hegemony of the Greek language held over both religious 
groups in the greater area, from Yanina to Korçë and from Preveza to Përmet, (see L. Baltsiotis,

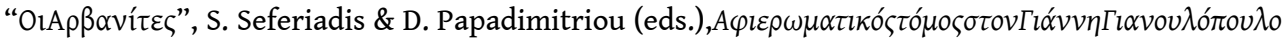
, Athens, 2011 (in press)).

15. See L. Embirikos, Histoire..., op. cit., pp. 106, 114.

16. It is quite characteristic that it was in 1880, when the British Valentine Chirol visited the Christian "Albanian" village of Tourkopalouko (today Kypseli, at the northwest part of the Preveza prefecture), that his confidence for his Greek friends in Yanina "was first shaken". He was surprised that no one in the village spoke or understood any other language than Albanian although his friends "had assured me that south [of the river] Kalamas there were no Albanian communities" (V. Chirol, "Twixt Greek and Turk, or Jottings during a journey through Thessaly, Macedonia and Epirus, in the Autumn of 1880",Blackwood's Edinbrurgh Magazine, n. 785, March 1881, p. 313).

17. See Dimitrios Hassiotis, $\Delta \imath \alpha \tau \rho \imath \beta \alpha i ́ \kappa \alpha l Y \pi o \mu v \eta ́ p \alpha \tau \alpha \pi \varepsilon \rho i ́ H \pi \varepsilon i ́ p o v, \alpha \delta \varepsilon \lambda \varphi o i ́ \Pi \varepsilon \rho \rho \eta ́, 1887$, pp. 51-52.

18. This is a continuously repeated assertion of Greek state officers.

19. The region that, according to the Greek claims, should have been included to Greece is

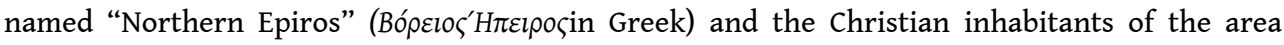

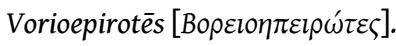

20. Under the term Northern Epirus is recognized, in Greek irredentist, nationalistic bibliography and public discourse, the area of today's Albania that includes Korçë, Gjirokastër and Himarë.

21. A typical example of this procedure is the bilingual edition of the (Greek) Army

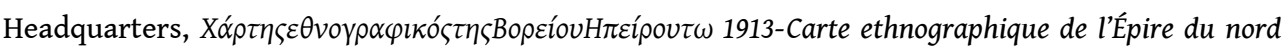

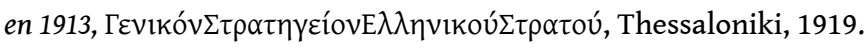

22. For example, the impartial, otherwise known by Greeks as "moderate" president of the Albanian Club of Yanina was assassinated in the summer of 1912, probably after an order of the pro-Greek League Ipirotiki Etairia (see L. Embirikos..., op. cit., p. 162).

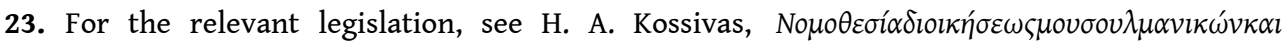

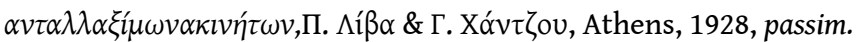

24. For instance the Muslims in Epirus were temporarily not permitted to freely move in the area (HAMFA, 1920, 151.4, The Staff of the Army to the Governor General of Epirus, 30.06.1919).

25. We mention for example, the restrictions for Muslim landowners to sell or hire their land after 1917, see Konstandinos Tsitselikis, Old and New Islam in Greece. Legal and Political aspects, (under publication), especially the chapter: "Property Rights on Real Estate Belonging to Muslims".

26. Ministry of Foreign Affairs 07.05.1918, Ministry of Agriculture 01.10.1918, The Government Commissary for Kozani and Florina January 1917 (HAMFA, 1918, B/AAK-1). For the 1917 decisions of the Council of Ministers not to implement the regulations concerning the abandoned plots in Epirus and its implementation at least by 1919 see K. Tsitelikis..., op. cit.

27. Bastaina is a kind of large scale property on which the farmer, although not owning the land, has more rights compared to a chiftlik farmer: The right of cultivation can be sold or inherited and the farmer can not be evicted from the land he cultivates.

28. Despite the myth that Chamouria had only chiftliks, comparisons with other areas show that Epirus in general had the same percentage of chiftlik distribution with that of Macedonia and

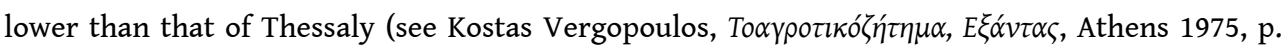
136).

29. For the variations in the political attitudes of the beys and the integration of part of them into modern society see Nathalie Clayer, Aux origines du nationalisme albanais. La naissance d'une nation majoritairement musulmane en Europe, Karthala, Paris, 2007, pp. 33-41.

30. According to a 1936 document, at the Muslim village of Liopsi there are 170 families. More than one hundred of them "prosper" as they own land at the Chamouria plain, the rest of them 
being "poor and driven to desperation", The Local Authorities Inspector [attached at the General Governance of Epirus], Jianina 30.07.1936, HAMFA, 1936, 21.1. At the document it is underlined that at the neighboring village of Kotsika 150 persons left to Turkey during 1926-1927, reducing the current (at 1936) population to 450. One can suppose that the emigrants were coming from the "poor" families, although further research should be undertaken.

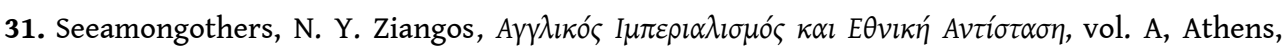
1978 p. 255, H. Minga, Çamëria, vështrim historik, Tirana, 2006, pp. 85-86.

32. We must add that some of the "volunteer" units who were fighting on the side of the Greek Army, were coming from the area. This factor, most probably contributed to the increase of armed clashes. For a more detailed narration of the fighting and the battles that occurred in the area during late 1912, the use of local population and the burning of villages by both sides see K.

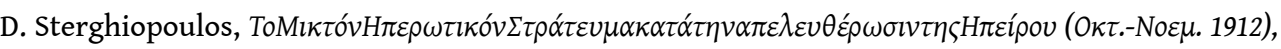
Athens, 1968.

33. See for example K. Naska (ed.)..., op. cit., pp. 1-104.

34. For example see HAMFA, The Vice-governor of Paramythia to the Ministry of Internal Affairs, 30.03.1917 (1917/A/4X(16)).

35. Two written examples that come to us from the Greek side can illustrate the point. At his diary, a Greek officer describes his sadness when he visited a mosque outside the city of Arta, at

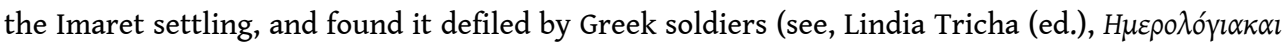

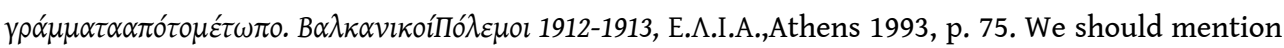
that no battle or resistance to the Greek Army took place in the Imaret area.

The lieutenant of the Greek Army Dimitrios (Takis) Botsaris, after a looting incident during the First Balkan War, pronounces an order that "from this time on every one who will dare to disturb any Christian property will be strictly punished" (see K.D. Sterghiopoulos..., op.cit., pp. 173-174). In pronouncing the order in this manner he left Muslim properties without protection. Botsaris, coming from Souli, was a direct descendant of the Botsaris' family and was fluent in Albanian. He was appointed as lieutenant in charge of a Volunteers' company consisting of persons originating from Epirus and fighting mostly in South Western Epirus.

36. For the Greek policy at the area during the first two years after the annexation to Greece see

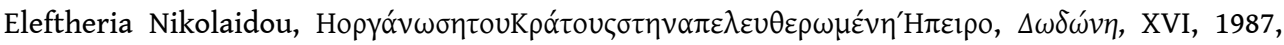
pp. 497-609.

37. K. Tsitselikis..., op. cit., H.A. Kossivas..., op. cit., passim.

38. K. Tsitselikis..., op. cit.

39. For the financial and social changes at the area during the last decades before the annexation

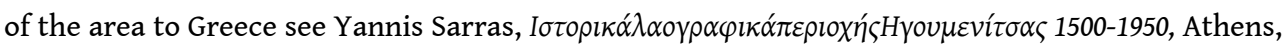
1985, passim. As the author puts it regarding the arrogant behaviour of Christians against Muslims "Muslims had restricted their reactions to Christians, in a self-defence mode, they were reacting only in the case that an offence against them was taking place" (ibid, p. 227). The gap created during late $19^{\text {th }}$ century between religious denominations of the Ottoman Empire is described in N. Clayer, Aux origins...,op. cit., pp. 540-549.

40. See Hajredin Isufi, "Politika e shtetit grek për dëbimin e popullsisë çame në vitet 1914-1928 dhe qëndresa shqiptare, Studime Historike, 1-4, 1993, pp. 60-77, Georgia Kretsi, "austauschbar nicht-austauschbar: Albanophone Muslime (Çamen) und andere Grenzbevölkerungen der Zwischenkriegszeit im Kräftefeld ethnischer Identitätskonstruktion und Entmischungspolitik", Jahrbücher zur Kultur und Gesellschaft Südosteuropas Bd. 4, pp. 205-231, pp. 225-226.

41. It's quite indicative that already by 1920 inhabitants of Margariti could be found serving in the Albanian Army (HAMFA, 1920/155.1, The 2/24 company (based at Margariti) to V Military Area Headquarters, doc. dated the $26^{\text {th }}$ of May 1920). For the fact that persons originating from Chamouria were serving in the Albanian army or were employees at the Albanian public services, 
see various documents at HAMFA, 1921.10.1. Most of them were coming from the area of Margariti, where a lot of Muslims were landless farmers.

42. This is an in-progress research concerning the on-line Archives of Ellis Island (see www.ellisisland.org), and the difficulties that the transliteration of names into English caused in handling its completion. The declaration of those people as belonging to the Albanian "Race or People" is not a safe proof of a national affiliation. The context of the question "Race or People" is not to be examined in this paper.

43. For some descriptions of the reactions of the Muslim population of the area against the Italian Army and their collaboration, see various documents at HAMFA, 1917, A/4/X (16) and 1916-1917, A/IV. In some cases the Muslims raised Italian flags. For the Muslims' "personal revenge" against local Christians see the document dated the $30^{\text {th }}$ of March 1917 of the SubGovernor of Paramythia to the Ministry of Foreign Affairs (HAMFA, 1917, A/4/X (16)).

44. HAMFA, 1920/155.1, The 2/24 company (based in Margariti) to V Military Area Headquarters, doc. dated the $26^{\text {th }}$ of May 1920 .

45. HAMFA, 1919, A/5/10, $\delta$, The General Governance of Epirus to the Ministry of Foreign Affairs, 23.05.1919.

46. Epirotes in this context means "pure Greeks". See. N. I. Anaghnostopoulos,

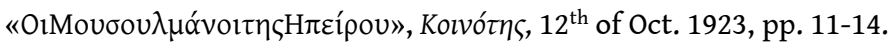

47. For the use of the Illyrian argument, in other words "the common ancestors of both the Albanians and the Greeks" in front of the League of Nations by the Greek Chargé d'Affaires in order to reconstruct the criteria of origin, see League of Nations, Official Journal, Feb. 1925, Annex 717, p. 247.

48. The Albanian claims on the Albanian speaking population of the areas of Kastoria [Kostur in Albanian] and Florina [Follorinë in Albanian] did not ensure the non inclusion of this Albanian speaking Muslim population in the Greco-Turkish exchange of populations. Nevertheless, these claims and related struggles were far from leading to any major bilateral or international debate.

49. According to a basically common legal process, a few hundred more individuals, Muslims, living mostly in urban centers declared themselves to be of "Albanian origin" and some others obtained Albanian nationality and thus avoided their inclusion in the exchange process. On the other hand the (Muslim) population of Preveza, and the majority of that of Yanina and of the small towns of Konitsa, Parga and Poghoniani (ex-Voshtina), were considered "Turks by origin" and were included in the exchange of the populations.

50. See Ioannis Nikolaidis, $\tau \alpha \Gamma \imath \alpha ́ v v \imath v \alpha \tau o v M \varepsilon \sigma o \pi \circ \lambda \varepsilon ́ \mu o v$, vol. VII, Yanina 1993, p. 104. These heavy restrictions were legally covering all Muslims, but they didn't affect those who were part of the exchange of populations as they left the country. For instance the prohibition of selling up to half of the gathering plot was quite hard for the farmers.

51. One stremma is 1,000 square meters, roughly one fourth of an acre.

52. The term garden we referred to what in Greek used to be called baxēs [from Turkish bahçe] or kêpos, an area usually adjoining the house, not larger than a few square meters were seasonal plants and groceries were being cultivated for domestic consumption.

53. HAMFA, 1935, A/4/9/2, the General Inspector of the Central Department (of the Ministry of Agriculture) to his Ministry, 29.09.1932.

54. HAMFA, 1935, A/4/9/2, the General Inspector of the Central Department (of the Ministry of Agriculture) to his Ministry, 07.08.1931. In most cases the compensations were not given until the early 1930s.

55. For an exemplary case see HAMFA, 1934 A/4/I/1, Ministry of Agriculture, nr. 141865/17.01.1934.

56. Until 1928 2,000,000 stremmata of large real estate of arable and non-arable land had been expropriated in Epirus out of 1,450,000 stremmata of arable land. The corresponding numbers are 2,550,000 and 8,760,000 stremmata for Macedonia and 2,730,000 and 4,000,000 stremmata for 


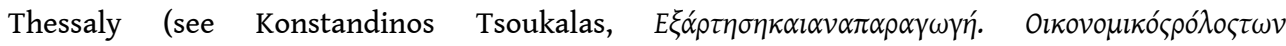

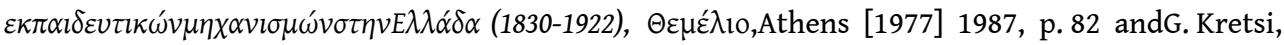
"FromLandholdingtoLandlessness. The Relationship between the Property and Legal Status of the Cham Muslim Albanians", JGKS 5, 2003, pp. 125-138).

57. See for example the document of the Ministry of Military Affairs to the Ministry of Foreign Affairs, dated 4 May 1925 in which the author vividly asks for the speediest departure possible of the Muslims for reasons of "military security in the frontiers" (HAMFA, 1925, Г/68/X).

58. It must be underlined though that there is little evidence to support that this was the result of a general, organized plan, but rather one among many other tactics followed by central and local officilas. For several reports of this indirect enforcement to leave Greece for Turkey see the 1922-1925 (and 1926) documents at Kaliopi Naska (ed.),..., op. cit. and Ibrahim Hoxha, Viset kombëtare shqiptare në shtetin grek, "Hasan Tahsini",Tirana 2000, passim (critical).

59. For example, that was the case with some families in Parga (interview with Mr H., İzmir 2007).

60. HAMFA, 1925, f. Г/68/X.

61. The great majority of the refugees were resettled when it was decided that the Muslim population would not be exchanged.

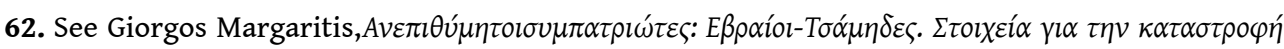

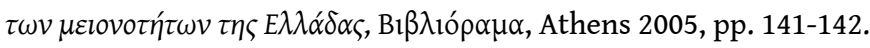

63. Expessions like "trying [financial] situation" or "miserable situation" are repeated at the administrative reports of the early 30s (see HAMFA 1935, A/4/9 /2, various documents).

64. Ibid, p. 143.

65. "For the sake of [Greek] national interests they should have been exchanged a long time ago", writes the Commander of the Corfu Garrison in his monthly report the $4^{\text {th }}$ of October 1924 (HAMFA, 1924, A/2/14). At that time Corfu was closely related with the opposite coast, that is, Chamouria and the Albanian ports.

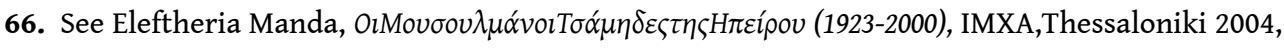
passim.

67. See others Konstandinos Tsioumis,

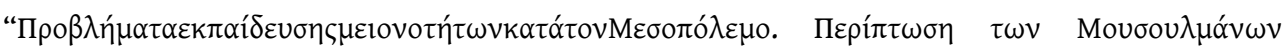

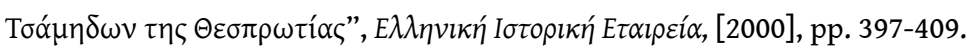

68. It is not until 1927 that Greek sources start referring to the Albanian language and schools issue. The following year the Albanian nationalists of Filiati tried to operate a female school, in which certain subjects were conducted in Albanian (see Lambros Baltsiotis research at L. Embirikos..., op. cit, pp. 163-164).

69. Inspection of the Elementary Schools of Paramythia [sub-prefecture], 27.02.1931, HAMFA, 1935, A/4/9.

70. From that time on, the documents coming from Ministries, the General Governance of Epirus and generally high rank officers are partly referring to "Albanians", "persons of Albanian origin", and not "Muslims" or "Ottomans" as they usually did in the past. (HAMFA, various files 1930-1937).

71. Report, 15.10.1930, Archive of Eleftherios Venizelos, Minorities, f. 58/173/4573. See the more detailed report on illegal real estate expropriations and confiscations and the financial results upon the Muslim population at the documents contacted by the General Inspector of the Central Department (of the Ministry of Agriculture) to his Ministry, dated 13. 01. 1932 and 07.08.1932 (HAMFA, 1935, f. A/4/9/2), where he underlines that even plots of 2-3 stremmata had been expropriated.

72. For example, even Ali bey Dino, a former MP and a member of the Greek intelligentsia was arrested for pro-Albanian propaganda as late as 1928 (see I. Nikolaidis, $\tau \alpha \Gamma \iota^{\alpha} v v \imath v \alpha \tau o v M \varepsilon \sigma o \pi \circ \lambda \varepsilon ́ \mu o v$, 
Yanina 1995, vol. VII, pp. 253-254). Ali bey Dino, not in fact connected with Albania, had raised a petition for the expropriations that took place at the village of Draghoumi in front of the League of Nations. For the land issue plus various other issues related to discrimination against Muslims see the Memorandum that a seven member committee dispatched to the dictator Theodoros

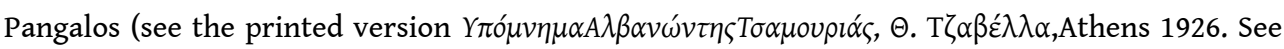
also K. Naska (ed.)..., passim and E. Manda..., op. cit., pp. 17-136.

73. See also above. The adventures of individuals or families that had initially chosen the Ottoman-Turkish nationality but remained in Greece as non-exchangeable ended in 1933 (HAMFA, 1934, B/2/IX, The Ministry of Foreign Affairs to the Ministry of Agriculture, 28.04.1933).

74. For the discriminatory policy of the Greek state in the Interwar period see also (To be read with a critical eye), E. Manda..., op. cit., pp. 25-132.

75. HAMFA, 1934/A/4/1, Petition of Y. Zordoumis et al. to the Governor General of Epirus (09.05.1931).

76. HAMFA, 1935. A/4/9/1, various documents.

77. HAMFA, 1935, A/4/9/3, Sub-prefecture of Thyamis to the Ministry of Foreign Affairs, 30.09.1932.

78. At 1935 the local Administration of the Gendarmerie of Preveza proposes the re-settlement of semi-transhumant families, namely skinitēs [in reality mostly Vlachs resided at the area, L. B.] in every Muslim village (see the document dated 30.05.1935 at HAMFA, 1935, A/21/I).

79. See for example the document: Ministry of Foreign Affairs, $\alpha . \pi .8089 / \mathrm{A} / 21 / \mathrm{I}, 12.08 .1932$ confirming the "definite settlement" of 17 Muslim (Cham according to the document) families from the sub-prefecture of Filiati to Turkey against one family to Albania for the year 1932 (HAMFA, 1935, A/21/I). According to another document regarding the sub-prefecture of Filiati for the year 1932, 86 Muslims settle to Turkey against 51 to Albania (The Sub-prefect of Thyamis to MFA,Filiati, 30.09.1932, HAMFA, 1935, A/21/I). The above document contains the higher ratio of persons migrating to Albania compared with those migrating to Turkey from a variety of documents found at the HAMFA.

80. General Administration of Epirus to the Sub-Prefecture of Thyamis, Yanina, 12.11.1932 (HAMFA, 1935, A/21/I).

81. For an attempt to record this migration see Ibrahim Hoxha..., op. cit., pp. 226-231, where more than 300 families are numbered.

82. See the note dated 13.01.1932, Minorities Section, Prime Minister's Bureau (HAMFA, 1935, A/ $4 / 9 / 2)$.

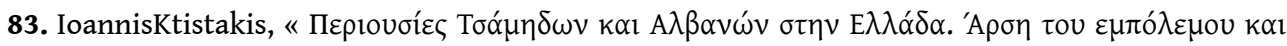

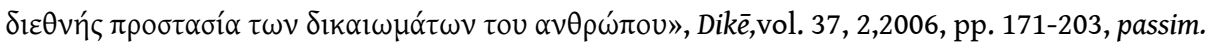

84. See indicatively the disapproval of the Gendarmerie proposal for the deprivation of the citizenship (through the erasure from the "Males Registration Roll") of Muslim Cham teachers residing in Albania and work in Albanian public schools for "reasons of purposefulness " (MFA to Governance General of Epirus, Athens, 15.10.1936). The "Légation de Grèce en Albanie" is much more clear when justifying its disapproval for the same case: If Greek authorities will not provide with (Greek) passports these teachers, Albania will act in a reciprocal way for the numerous teachers originating from Greece and teaching in the minority schools in Albania (The Greek Delegation [Embassy] in Albania to MFA, Tirana, 23.01.1936 (HAMFA, 1936, $\varphi .21$ ).

85. At middle 1936 the Greek Ambassador at Tirana complains to his Ministry for the reason that he had been informed by civilians for the "measures" taken in Chamouria. He writes that the "extremely hard and brutal measures" taken against Chams were the result of the initiatives of the Gendarmerie Officer Stavridis, originating from "Northern Epirus", who was manipulated by various individuals (The Greek Delegation [Embassy] in Albania to MFA, Tirana, 22.06.1936, HAMFA, 1936, $\varphi .21)$. 
86. See E. Manda..., op. cit., pp. 100-108, K. Naska (ed.)..., op. cit., pp. 662-699, L. Baltsiotis research at L. Embirikos..., op. cit., pp. 165-172.

88. Quite vividly the Greek Communist Party newspaper Rizospastis refers to the "Unimaginable suffering of the Chamouria Albanians" (29.11.1934) and the "Scandalous misbehaviours of the Greek authorities in Chamouria" (12 and 13.12.1934).

89. Official Journal, League of Nations, Dec. 1936 (C. 292.1936.I), pp. 1415-1417. Notice the use of the word idiom instead of language.

90. According to the suggestion of the General Administration of Epirus to the Ministry of Foreign Affairs (the 24th of October 1936), the presence of Albanian Muslims and the difficulties in "administrating" them from a far away capital calls for the creation of a new prefecture (HAMFA, 1937, A4/9).

91. Yanina, 28.03.1936, HAMFA, 1936, $\varphi .21$.

92. In this way, only 20 non-Muslim Albanian-speakers are recorded in Epirus. It's only in Macedonia that 1,119 persons are listed, leading to a total of 18,773 Albanian speakers for all of

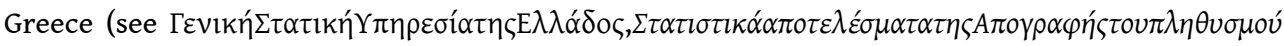

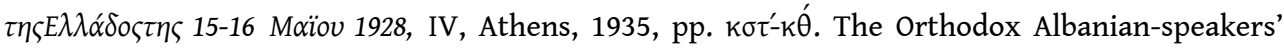
"return" to Southern Greece and Epirus, Macedonia and Thrace also present at this time, at the 1951 census (7,357 are counted in Epirus). Only in the 1940 census, never completed due to the beginning of War, Muslim and Orthodox Albanians appear (32,712 Orthodox and 16,899 Muslims, the vast majority of the latter residing in Epirus (see L. Baltsiotis, L'albanophonie..., op. cit., pp. 170-171).

93. See the document "The Social Security Ministry to the Ministry of Foreign Affairs, 25.02.1933", HAMFA, 1938, f. 23: "For the dissemination of the Greek language in both the population of Albanian speaking homogeneis and Turcoalbanians".

94. HAMFA, 1935, A/4/3, The VIII Division to the Ministry of Military Affairs, 13.08.1935.

95. At that time Albania had become an Italian protectorate. Muslim Chams, being unofficially considerd Albanians, eventually were treated as hostile population.

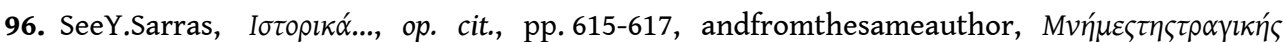

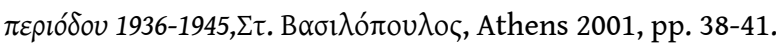

97. See I. Hoxha..., op. cit., pp. 309-320. The Greek authorities classified them as "political

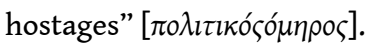

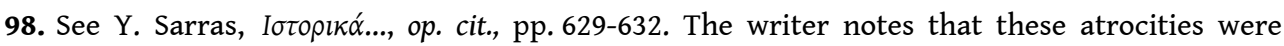
undertaken under the "State's tolerance" and that even civil servants took part in them.See also

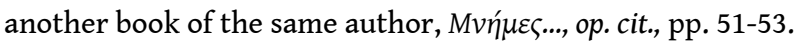

99. For the negotiations and the agreements concerning the expropriated land see G. Margaritis..., op. cit., pp. 156-159, E. Manda..., op. cit., pp. 144-145. It's quite interesting in that sense to look at the way the Chams were reacting at the tax collection (see the Report of the Financial Inspector of the Ministry of Finance, dated the $22^{\text {nd }}$ of June of 1942 at G. Margaritis..., op. cit., pp. 182-183).

100. The highest semi-documented number of Greeks murdered or killed, armed or not, is around 450 for the Prefecture of Thesprotia and 46 for that of Preveza (See, the relevant Report

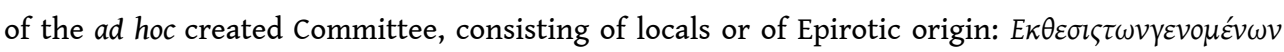

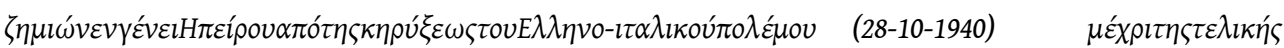

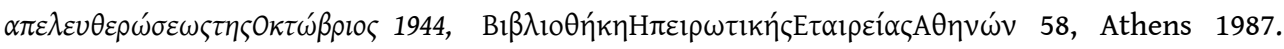
Another Greek source counts roughly 450 Christians who died of non natural causes between 1940-1945 (see the extended report of the Greek National Bureau of War Crimes to the Ministry of Foreign Affairs, dated the $19^{\text {th }}$ of July 1946, Filippos Dragoumis Archive, f. $73 / 3$, doc. 106). As it is expected there is not a single word mentioning the atrocities against the Muslim population. In light of other sources, we think that a number of 300 to 350 can easily be verified. Higher 
estimations include some double registrations as N. Y. Ziangos has demonstrated (see N. Y. Ziangos..., op. cit., vol. A, pp. 250, 254, 265-266).

101. Ses Y. Sarras, Mv $\eta \dot{\mu} \varsigma$..., op. cit., pp. 71-73. This incident is, from our point of view, quite characteristic of a different way of thinking and acting in this period, as the notions of right and justice had different meanings in those communities compared to today.

102. Despite social democratic elements in its program and discourse, EDES gradually followed an anti-communist path, loyal to the right wing political powers existing prior to WWII in Greece. 103. For the case of Paramythia see E. Manda..., op. cit., pp. 178-182, where the writer tries to identify the reasons of the massacre. It is widespread in the local discourse that the Paramythia slaughter was a justified act of revenge against the execution of the 45 (Christian) notables of the town that took place during the Occupation with the participation, if not the instigation, of the Muslim Chams.

104. According to a "name and place of origin list", more than 1,200 were murdered. This number does not include armed men killed during fights or skirmishes with the Greek guerilla forces. Their name list counts 260 persons, several dozens of them coming from the Konispol area (see I. Hoxha..., op.cit., pp.449-499). The Memorandum of the Anti-fascist Committee of the Çami Immigrants in Albania to the United Nations Security Council counts 2, 877 victims (See G. Margaritis..., op. cit., p. 211). Some hundreds of Chams died in Albanian territory due to hardships experienced after the evacuation of Chamouria.

105. Some of them returned in early 1945 , when the ELAS left wing guerrillas temporarily took control of the area, and fled again to Albania, after being attacked by EDES once more and losing nearly one hundred more souls. For a general but very well-focused description of the 1940-1945 period see Georgia Kretsi, "The "Secret" past of the Greek-Albanian Borderlands. Cham Muslims Albanians: Perspectives on a Conflict over Historical Accountability and Current Rights", Ethnologia Balkanica, vol. 6, 2002, pp. 171-195. For a glossing over of the atrocities committed against the Greeks and an emphasis on the Muslims' antifascist contribution, see, Beqir Meta, "Spastrimi etnik i popullsisë shqiptare muslimane të Çamërisë", Univers 1(Tirana), 2001, pp. 83-96.

106. Except for two small communities that mostly avoided conversion, namely Kodra and Koutsi (actual Polyneri), the majority of others were baptized. Isolated family members that stayed behind were included in the Greek society, and joined the towns of the area or left for other parts of Greece (author's field research in the area, 1996-2008).

107. E. Manda,..., op. cit., pp. 162-163.

108. See above and ibid, p. 204.

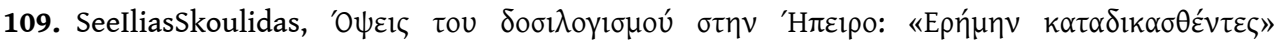
Tбá $\mu \eta \delta \varepsilon \varsigma »$, Egnatia, (inpress).

110. I. Ktistakis..., op. cit.

111. Without discussing in detail the legislation that permitted this take over by the state, it should be underlined that some of the legislation was primarily used for the communist guerrillas that fled the country after the end of Civil War at 1949. It's quite difficult to track the exact legislation that was implemented in every case: Urban and rural land is occupied

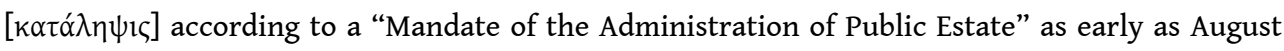
1945 for the urban land and late September for the rural one (archive of the author).

112. Ibid.

113. See Tassos Kostopoulos' contribution in this volume.

114. See the relevant legislation at I. Ktistakis..., op. cit.

115. We adopt the term ethnic cleansing although it was formed at the nineties during the Yugoslav Wars. Concerning the history and the use of this term, see Alice Krieg-Planque, "Purification ethnique". Une formule et son histoire, CNRS,Paris, 2003. 
116. See for instance the report of the Greek National Bureau of War Crimes to the Ministry of Foreign Affairs above.

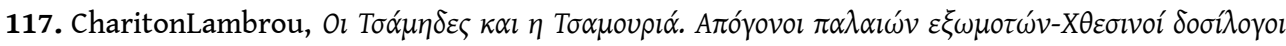

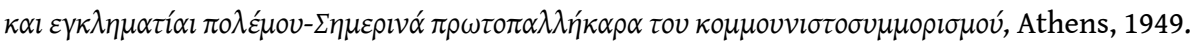

118. For the manipulation of numbers see below.

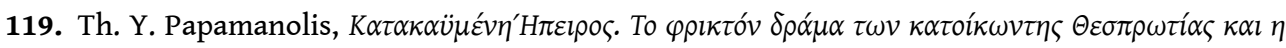

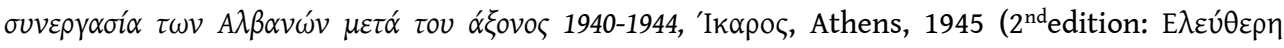
$\Sigma \kappa \varepsilon ́ \psi 1 \varsigma, A \theta \eta ́ v \alpha, 1999)$. We note that the writer claims that EDES should not have treated the Chams in such a ... "conciliatory manner"(ibid, p. 149).

120. G. Margaritis..., op. cit., p. 134.

121. For those manipulations see below.

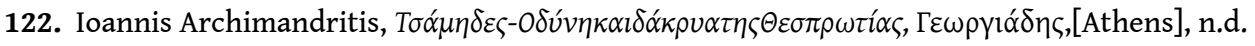

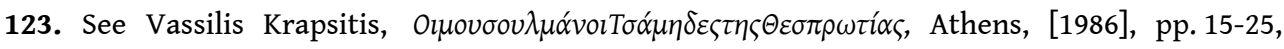
130-133, 170-172.

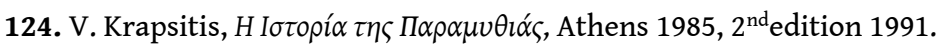

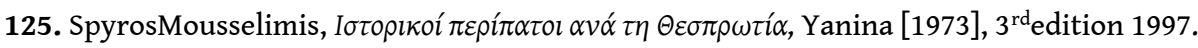

126. L. Embirikos emphasizes the fact that in the case of Christians we face an "occultation totale ","total occultation" even by the left wing local writers who dare to deal with the 1944-1945 incidents in a more objective way (see L. Embirikos..., op. cit., p. 189).

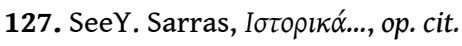

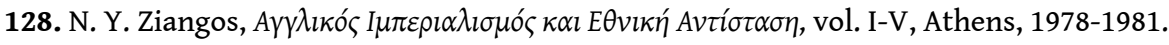

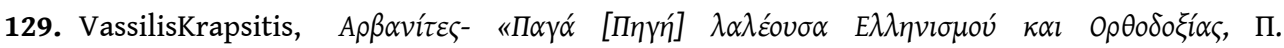

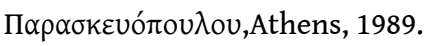

130. See L. Baltsiotis, L'albanophonie..., pp. 100, 107.

131. Dimitris Michalopoulos, "The Moslems of Chamuria and the exchange of populations between Greece and Turkey", Balkan Studies 27, (Thessaloniki) 1986, pp. 303-313, p. 304. Vassilis

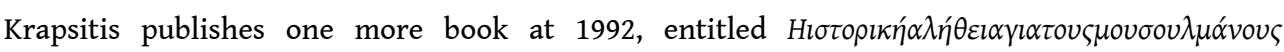

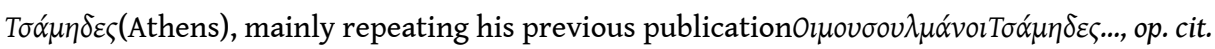

132. According to an interview given by Ramiz Alia to the Greek journalist Tassos Telloglou (see Telloglou's presentation "How attractive is the Cham issue in today's Albania?", in the conference organized by the Minorities' Research Group Center entitled "The Cham issue. History and current trends", held at Panteion University, Athens the $21^{\text {st }}$ of February 2008).

133. As Georgia Kretsi points "the persecution of the Albanian Muslim minority was not even mentioned in history text books [in Albania]" (G. Kretsi, “The "Secret” Past..., op. cit., p. 190).

134. L. Embirikos..., op. cit., p. 211. He collected five cases where relics of Albanian speech of the area were published, plus one more in a purely scientific revue. In one case the local writer just presents some words in order to prove their relation with the ancient Doric Greek dialect (ibid, pp. 212-213).

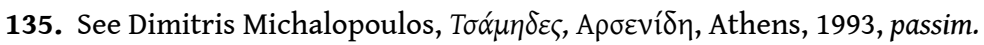

136. Some of them, written by individuals with an ultra nationalistic, far-right background, tried to create an atmosphere of paranoia and conspiracy theories, going as far as to talk about

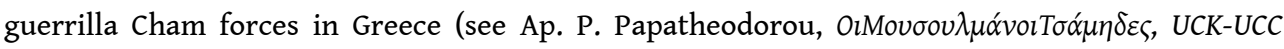

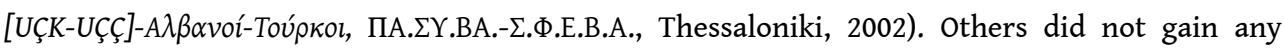
popularity even by the local audience such as the book of Ch. N. Tsakas, $\tau \alpha \varepsilon \gamma \kappa \lambda \eta \dot{\eta} \mu \alpha \tau \alpha \tau \omega \nu T \sigma \alpha \dot{\mu} \mu \eta \omega \nu$

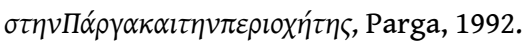

137. See for example the booklet by the associate professor of the Theological School at

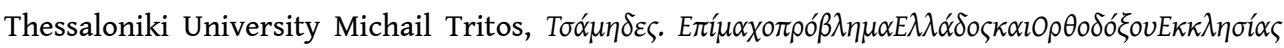

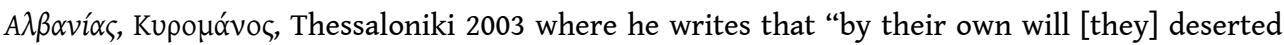
Thesprotia, afraid of the sentences they could face from Greek Justice for their unacceptable 
atrocities [...] against local Greeks" (p. 11). He supports their Greek origin and gives the number of Muslims in 1940 at 16,661.

138. See L. Baltsiotis, L'albanophonie..., op. cit, pp. 277-279.

139. Indicatively, the figure for Parga has no Muslim inhabitants in contrast to 150 Muslims in that of Krapsitis' counting.

140. For example, for Perdika (ex-Arpitsa), at that time a big Muslim village with a small Christian community consisting mainly of refugees, he gives the figure of 1649 Christians and 130 Muslims while Krapsitis gives the figure of 150 Christians and 1600 Muslims (see a more detailed description at L. Baltsiotis, L'albanophonie..., op. cit., pp. 591-594).

141. For instance, the figure for the Muslim population of Syvota (ex-Mourtos or Volia) in Krapsitis is 310 persons, while in a document of 1932, following the 1928 census, the sub-prefect of Thyamis records 679 inhabitants (HAMFA, 1935, A/4/9, The sub-prefect of Thyamis to the Bureau of the Prime-Minister (Filiati the $21^{\text {st }}$ of March 1932). Mourtos, a purely Muslim settlement, was not a village with a large influx of emigrants to Albania and Turkey and the figure given by Krapsitis can not be supported by the relevant evidence. Theofficial 1940 censuspublicationscount 883 residentsatSyvota (see $\tau \tau o l x \varepsilon i ́ \alpha \sigma v \sigma \tau \alpha \dot{\sigma} \sigma \varepsilon \omega \varsigma \kappa \alpha l \varepsilon \xi \varepsilon \lambda i \xi \xi \omega \varsigma \tau \omega v \Delta \eta \dot{\eta} \mu \omega v \kappa \alpha l$

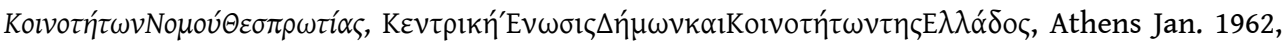
p. 37).

142. Slavic-speaking Macedonians being the spine of the communist Democratic Army of Greece ( $\Delta \Sigma E$ ) during the Civil War, found some support amongst the leftists in Greece.

143. A rather striking example of this erasure can be identified in a special supplement dedicated to Epirus, attached to the Sunday edition of a top selling and respected Greek newspaper. There are a lot of references to the Aromanian speaking Vlachs, even a reference to the half dozen slav-speaking villages of mount Grammos, almost uninhabited, but not the

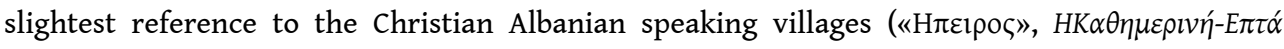

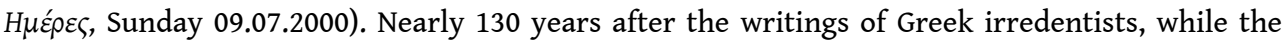
Slav presence is acceptable in Epirus, the Albanian one is not.

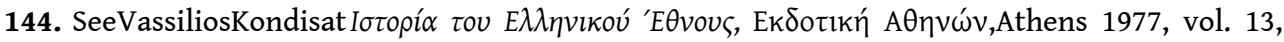
pp. 387-394, 388-389. The Suha line is not an invention of the writer, but of the irredentist Greek policies of the last quarter of nineteen century.

145. Interview in 2000, ex-mayor of Paramythia appointed during the dictatorship.

146. Today there are only three semi-demolished minarets standing, one in Margariti, the other in Katavothra and the third one in Kotsika.

147. No process of pursuing charges against the offender took place (Author's field research 2004).

148. Author's field research $1997-2008$.

149. This article was later modified and entered the Greek Nationality Code (Act) as article 19, which was in force until 1998.

150. Another relevant order was sent at the $29^{\text {th }}$ of Dev. 1947 entitled "Erasure of the Males Registration Roll of Muslims of Albanian origin" (Ф.9905/13/A2/III, General Headquarter (Г.Е.ऽ.)). Both documents are in the author's personal archive.

151. On the contrary Slav-Macedonians and Turks that were deprived of the Greek nationality "exist" in the registries with the specific indication concerning the deprivation of their nationality, the number of the relevant decision and the legal basis.

152. After the petition of M. D. to the Municipality of Paramythia concerning his registration at the Municipality records, the Mayor for the years 1998 and 1999 justifies in three different ways on the issue of the "non existence" of the relevant registration (author's personal archive).

153. This affected a few dozens persons. These data result from the author's unpublished research in the Council of Citizenship Archives. 
154. The protagonist of the expulsion, N. Zervas, in a letter to one of his comrades, dated 1953 writes: "Our fellow country men of the area must recall once more who got rid of the Muslim Chams [Arvanitēs at the text] who were pushing down the neck of Hellenism for five hundred years". The letter is published at the book of Sp. Mousselimis , op. cit., pp. 103-104 and there is no doubt so far of its authenticity.

155. Georgia Kretsi, "From Landholding...", op. cit., p. 136.

156. As Georgia Kretsi puts it "[I]t is arguable that the social process of minoritization of the Cham group was intimately linked to a politics of possession and dispossession" (See ibid, p. 126). 157. The absence of scholarly works in Greece concerning the Cham issue up to the late eighties is not due only to self-censorship in the academic community. It's also the result, according to our view, of the erasure process that took place.

INDEX

Keywords : Chams, Demographic engineering, Epirus, Greece, Muslims, Orthodox

Mots-clés : Chams, Épire, Grèce, Ingénierie démographique, musulmans, orthodoxes 